\title{
Productivity response of calcareous nannoplankton to Eocene Thermal Maximum 2 (ETM2)
}

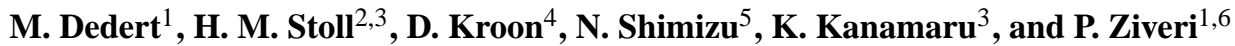 \\ ${ }^{1}$ Cluster Earth \& Climate Department of Earth Sciences, Faculty of Earth and Life Sciences, \\ Vrije Universiteit Amsterdam, 1081HV Amsterdam, The Netherlands \\ ${ }^{2}$ Dept. de Geologia, Universidad de Oviedo, Asturias, Spain \\ ${ }^{3}$ Geosciences Department, University of Massachusetts at Amherst, Amherst, MA, USA \\ ${ }^{4}$ School of GeoSciences, University of Edinburgh, Edinburgh, UK \\ ${ }^{5}$ Department of Geology and Geophysics, Woods Hole Oceanographic Institute, Woods Hole, MA, USA \\ ${ }^{6}$ ICTA, Autonomous University of Barcelona (UAB), Bellaterra, Spain
}

Correspondence to: M. Dedert (m.dedert@vu.nl)

Received: 27 April 2011 - Published in Clim. Past Discuss.: 23 June 2011

Revised: 26 November 2011 - Accepted: 3 January 2012 - Published: 31 May 2012

\begin{abstract}
The Early Eocene Thermal Maximum 2 (ETM2) at $\sim 53.7 \mathrm{Ma}$ is one of multiple hyperthermal events that followed the Paleocene-Eocene Thermal Maximum (PETM, $\sim 56 \mathrm{Ma})$. The negative carbon excursion and deep ocean carbonate dissolution which occurred during the event imply that a substantial amount $\left(10^{3} \mathrm{Gt}\right)$ of carbon (C) was added to the ocean-atmosphere system, consequently increasing atmospheric $\mathrm{CO}_{2}\left(p \mathrm{CO}_{2}\right)$. This makes the event relevant to the current scenario of anthropogenic $\mathrm{CO}_{2}$ additions and global change. Resulting changes in ocean stratification and $\mathrm{pH}$, as well as changes in exogenic cycles which supply nutrients to the ocean, may have affected the productivity of marine phytoplankton, especially calcifying phytoplankton. Changes in productivity, in turn, may affect the rate of sequestration of excess $\mathrm{CO}_{2}$ in the deep ocean and sediments. In order to reconstruct the productivity response by calcareous nannoplankton to ETM2 in the South Atlantic (Site 1265) and North Pacific (Site 1209), we employ the coccolith $\mathrm{Sr} / \mathrm{Ca}$ productivity proxy with analysis of well-preserved picked monogeneric populations by ion probe supplemented by analysis of various size fractions of nannofossil sediments by ICP-AES. The former technique of measuring $\mathrm{Sr} / \mathrm{Ca}$ in selected nannofossil populations using the ion probe circumvents possible contamination with secondary calcite. Avoiding such contamination is important for an accurate interpretation of the nannoplankton productivity record, since diagenetic processes can bias the productivity signal, as we demonstrate for $\mathrm{Sr} / \mathrm{Ca}$ measurements
\end{abstract}

in the fine $(<20 \mu \mathrm{m})$ and other size fractions obtained from bulk sediments from Site 1265. At this site, the paleoproductivity signal as reconstructed from the $\mathrm{Sr} / \mathrm{Ca}$ appears to be governed by cyclic changes, possibly orbital forcing, resulting in a $20-30 \%$ variability in $\mathrm{Sr} / \mathrm{Ca}$ in dominant genera as obtained by ion probe. The $\sim 13$ to $21 \%$ increase in $\mathrm{Sr} / \mathrm{Ca}$ above the cyclic background conditions as measured by ion probe in dominating genera may result from a slightly elevated productivity during ETM2. This high productivity phase is probably the result of enhanced nutrient supply either from land or from upwelling. The ion probe results show that calcareous nannoplankton productivity was not reduced by environmental conditions accompanying ETM2 at Site 1265 , but imply an overall sustained productivity and potentially a small productivity increase during the extreme climatic conditions of ETM2 in this portion of the South Atlantic. However, in the open oceanic setting of Site 1209, a significant decrease in dominant genera $\mathrm{Sr} / \mathrm{Ca}$ is observed, indicating reduced productivity.

\section{Introduction}

The present rapid increase of greenhouse gases in the atmosphere has led to an increased interest in similar transient warming events that occurred in the geological past. The best-characterized events include a series of hyperthermals in the latest Paleocene to Early Eocene, all characterized by 


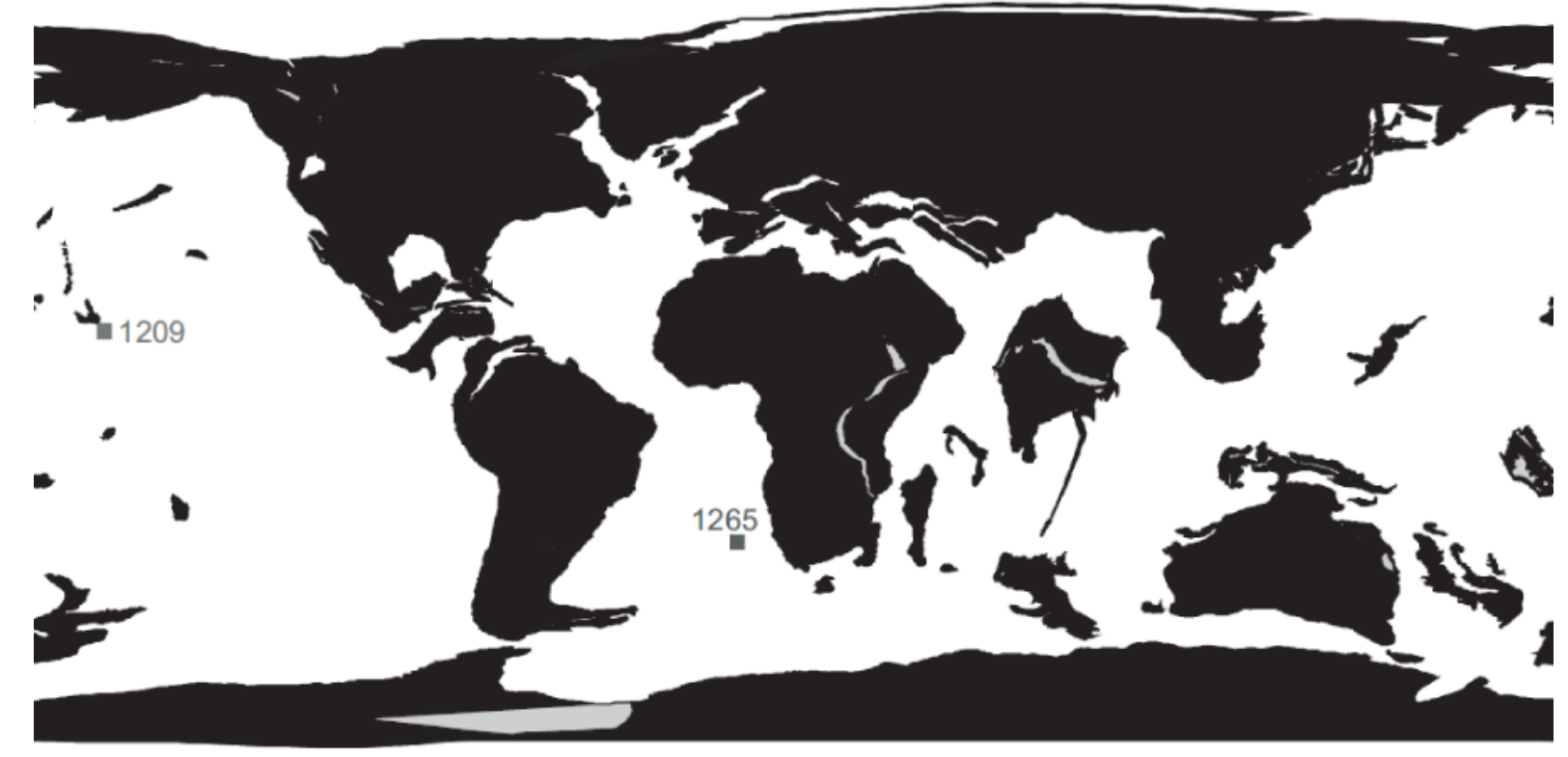

Fig. 1. (a) Map showing the paleogeographic reconstruction for the Early Eocene with the location of ODP Sites 1265 and 1209 (www.osdn.de).

negative C-isotope excursions and dissolution of deep-sea carbonates in large areas of the ocean, which together suggest addition of carbon $(\mathrm{C})$ to the atmosphere and transient increases in atmospheric $\mathrm{CO}_{2}$ (Cramer et al., 2003). All events also show transient warming believed to result from the increased $\mathrm{CO}_{2}$, as well as biotic responses such as a decrease in benthic foraminifera species richness. The largest event was the Paleocene-Eocene Thermal Maximum (PETM; 56 Ma) (Westerhold et al., 2009); others of smaller magnitude followed the PETM in the early Eocene (Lourens et al., 2005; Nicolo et al., 2007). We focus here on one of these later hyperthermals, the Eocene Thermal Maximum 2 (ETM2) at $\sim 53.7 \mathrm{Ma}$, first recognized by Lourens et al. (2005) on the Walvis Ridge, South Atlantic. The ETM2 at this location is characterized by a negative Carbon Isotope Excursion (CIE) of $\sim 1,5 \%$ in bulk carbonates and a low carbonate content interval (Elmo horizon) resulting from shoaling of the lysocline.

Marine phytoplankton may have been affected in several ways by the hyperthermals. First of all, if the deep-sea dissolution was also accompanied by surface ocean acidification, then the dominant eukaryotic plankton of that time, the calcareous nannoplankton (Falkowski et al., 2004), may have been adversely affected if calcification was compromised (Riebesell et al., 2000; Krug et al., 2011). Secondly, nutrient availability may have been compromised by increased thermal stratification in the photic zone, although enhanced continental weathering (Ravizza et al., 2001) or orbitally forced upwelling processes (e.g. Sloan and Huber, 2001) may have increased nutrient supply in the photic zone in certain areas of the ocean. The response of marine productivity to the PETM is also relevant to understanding the climate recovery, as increased productivity of marine phytoplankton could have functioned as a negative feedback to high $\mathrm{CO}_{2}$ concentrations by sequestering excess carbon in the deep ocean (through the biological pump) and in sediments. Calcareous nannoplankton was the key eukaryotic primary producer in marine ecosystems until about $35 \mathrm{Ma}$ (Falkowski et al., 2004); because larger eukaryotic plankton are exported more efficiently than picoplankton (Sweeney et al., 2003), the ballasting role of coccolithophores (Klaas and Archer 2002; Ziveri et al., 2007; Balch et al., 2010) would have been even more significant as the export production was likely closely tied to production by this calcareous plankton. As such, any changes in their productivity could have had a significant impact on the carbon cycle through the formation of organic matter and its effective ballasting by calcite scales. It is still under debate whether high $\mathrm{CO}_{2}$ conditions during hyperthermal events have had detrimental effects on calcifying organisms, such as calcareous nannoplankton (Gibbs et al., 2006a; Rigdwell and Schmidt, 2010). In some locations, calcareous nannoplankton productivity exhibited unique responses during the PETM (Gibbs et al., 2006b, 2010), but the PETM differed from other hyperthermals such as ETM2 in both magnitude (Lourens et al., 2005) and mechanisms, e.g. orbital forcing (Sexton et al., 2011), and may have been unique. Here we focus on the calcareous nannoplankton response to ETM2 to evaluate if there were similar patterns of changes in productivity. We focus on the Walvis Ridge in the South Atlantic and exhibit complementary data from the Shatsky Rise in the North Pacific (Fig. 1). 

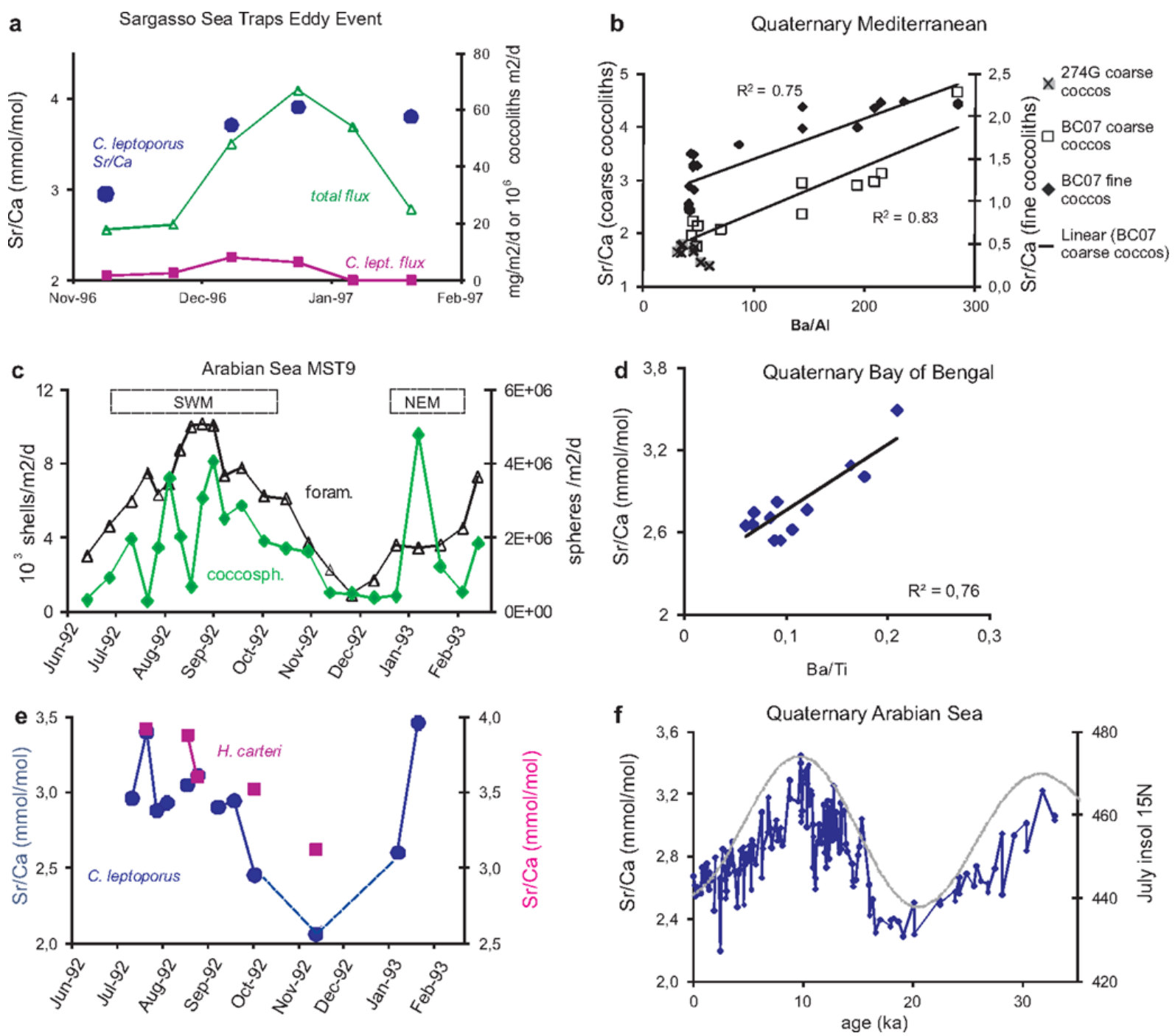

Fig. 2. Figures showing the relationship between coccolith $\mathrm{Sr} / \mathrm{Ca}$ and coccolithophore productivity (from Stoll et al., 2007b). (a) Sr/Ca in picked $C$. leptoporus in Ocean Flux Program (OFP) sediment traps during increased export production (total and in C. leptoporus coccolith fluxes) triggered by passage of a mode water eddy. (b) Coccolith $\mathrm{Sr} / \mathrm{Ca}$ plotted against Ba/Al productivity indicator. Fine coccolith fraction is dominated by E. huxleyi and coarse coccolith fraction by $H$. carteri (Eastern Mediterranean, Site BC07, $\sim 15 \mathrm{Ka}$ to present), including the early Holocene high productivity interval recorded in sapropel S1. Ba/Al is from nearby core GL94. Also shown are Sr/Ca in coarse H. carteri-dominated coccolith fraction from Western Mediterranean (274G) that features no sapropel or evidence of enhanced production in the early Holocene. (c, e) $\mathrm{Sr} / \mathrm{Ca}$ in picked C. leptoporus and H. carteri in sediment traps from the Arabian Sea (MST9) covering a seasonal cycle of summer upwelling and high productivity during the southwest monsoon (SWM), and low productivity during the autumn intermonsoon, and high productivity during strong wind-triggered nutrient entrainment of the winter northeast monsoon (NEM). (d) Sr/Ca of picked $C$. leptoporus plotted against the $\mathrm{Ba} / \mathrm{Ti}$ productivity indicator from Northern Bay of Bengal (RC12-343) from the penultimate glacial-interglacial transition. (f) $\mathrm{Sr} / \mathrm{Ca}$ of C. leptoporus-dominated size fraction from Core 905, Somali Basin, Arabian Sea, and insolation for July at $15 \mathrm{~N}$ (dashed gray line). Precessional maxima in summer insolation, and corresponding minima in winter insolation, drive a stronger summer upwelling and strong winter wind mixing, respectively, thereby boosting higher productivity.

In this study we use $\mathrm{Sr} / \mathrm{Ca}$ in nannofossil calcite to reconstruct changes in primary productivity of calcareous nannoplankton. Because the $\mathrm{Sr} / \mathrm{Ca}$ of primary nannofossil calcite is set in the surface ocean, unlike many other productivity indicators which rely on accumulation rates of biogenic components, it is unaffected by changes in preserva- tion rate or sediment accumulation rate. This is a considerable advantage for hyperthermal events for which changes in deepwater oxygenation state (Chun et al., 2010; Sexton et al., 2011) and accumulation rates (Torfstein et al., 2010) are well-documented. Culture and field studies reveal coccolith $\mathrm{Sr} / \mathrm{Ca}$ to be a good measure for the productivity of 
coccolithophores (Rickaby et al., 2002; Stoll et al., 2002a, b, 2007a). In sediment traps and Quaternary sediments, coccolith $\mathrm{Sr} / \mathrm{Ca}$ shows consistent primary relationships with known productivity forcing and with other productivity proxies, such as excess $\mathrm{Ba}$ and accumulation rates of alkenones (Fig. 2). In addition, a modest influence of temperature $(\sim 1$ to $2 \%$ per ${ }^{\circ} \mathrm{C}$ ) was demonstrated during culture experiments (Stoll et al., 2002a; Rickaby et al., 2002). The indicator works most effectively for investigating short-term productivity changes, such as ETM2, because variation in seawater $\mathrm{Sr} / \mathrm{Ca}$ on short timescales is attenuated to $<2 \%$ due to the long $\left(10^{6} \mathrm{yr}\right)$ residence times of $\mathrm{Sr}$ and $\mathrm{Ca}$ in seawater (Stoll et al., 1998). Nonetheless, these primary relationships can be partly obscured by addition of secondary diagenetic calcite in older sediments, so it is of high importance to use strict sample selection and analytical techniques that allow us to minimize and assess the role of diagenetic overprinting. Our strategy is to measure $\mathrm{Sr} / \mathrm{Ca}$ on individually picked well-preserved placoliths for reconstruction of productivity trends at the time of ETM2. At the Walvis Ridge site, we compare $\mathrm{Sr} / \mathrm{Ca}$ in these individually selected, well-preserved liths with $\mathrm{Sr} / \mathrm{Ca}$ of nannofossil dominated size fractions to calculate the degree of overgrowth, which we observe to vary over time, consistent with our characterization of nannofossil preservation via scanning electron microscopy (SEM). To better evaluate the long-term context for productivity change at the Walvis Ridge site, we analyze the $\mathrm{Sr} / \mathrm{Ca}$ of the integral coccolith fraction $(<20 \mu \mathrm{m})$ throughout the $200 \mathrm{ka}$ interval containing the ETM2.

\subsection{Methods and materials}

At Walvis Ridge, samples were taken from Hole 1265A, one of the shallowest sites ( $1500 \mathrm{~m}$ paleodepth) taken on a depth transect recovered on the Walvis Ridge during Ocean Drilling Program Leg 208 (Zachos et al., 2004). The CIE, an interval characterized by a gradual shift towards lighter $\delta^{13} \mathrm{C}$ values, signifies the release of $\sim 440-1600 \mathrm{Gt}$ of carbon in case of methane $\left(\delta^{13} \mathrm{C}-60 \%\right)$ or $\sim 1000-4500 \mathrm{Gt}$ carbon in case of organic carbon $\left(\delta^{13} \mathrm{C}-22 \%\right)$ into the biosphere (Zachos et al., 2010). The propagation of this carbon into the marine system resulted in shoaling of the lysocline and a drop in $\mathrm{CaCO}_{3}$ content from generally high ( $\sim 90$ to $\left.95 \%\right)$ to $\sim 54 \%$. This effect on the sediment archive was identified by shipboard MS and reflection data as a distinct layer, called the Elmo horizon (Lourens et al., 2005; Stap et al., 2009) (Fig. 3c). At Shatsky rise, samples were taken from Hole 1209A, which had an estimated paleodepth of $2400 \mathrm{~m}$ (Bralower et al., 2002a). During ETM2, a shoaling of the lysocline and drop in $\mathrm{CaCO}_{3}$ content is indicated by a minimum in $L *$ reflectance values at $192.325 \mathrm{mbsf}$ (Bralower et al., 2002a) (Fig. 4b), and $\mathrm{CaCO}_{3}$ and coarse fraction data (Murphy et al., 2005).

To ascertain productivity variations, we produced timeseries records for the dominant placolith taxa, which, by analogy with modern placolith-bearing coccoliths (Young et al., 1994) are inferred to be characteristic of upper photic zone production. These data are complemented by measurements on two nannolith genera whose ecological affinity is not clear, but could include a deeper photic habitat (Aubry et al., 1998). The placoliths employed for this Eocene study are the same genera (in the case of Coccolithus) or same lineage (in the case of Toweius) as the dominant species in the modern ocean (Bown et al., 1998), and therefore it is reasonable to assume that the geochemical response in Eocene nannofossil assemblages is comparable to extant taxa. For reconstruction of productivity variations at both Walvis Ridge and Shatsky Rise, we applied the method developed by Stoll et al. (2007c) that makes it possible to measure $\mathrm{Sr} / \mathrm{Ca}$ in monogeneric samples of nannofossil calcite, allowing for reconstruction of productivity response of individual nannofossil taxa without geochemical contamination by carbonate of other origin, or influence of alteration of primary calcite.

The method for isolating nannofossils for ion probe $\mathrm{Sr} / \mathrm{Ca}$ analyses is described in detail by Stoll et al. (2007b) and Stoll and Shimizu (2009). We have picked both placoliths, the circular plates (coccoliths) common to modern dominant genera of coccolithophores, such as extant species Emiliania huxleyi or Gephyrocapsa oceanica, as well as several genera of nannoliths, which are non-coccolith morphologies produced by haptophytes, or objects produced by biologically distinct, but ecologically similar phytoplankton groups (Bown et al., 2004). Common placolith-bearing genera from our site include Coccolithus pelagicus, Toweius, and Chiasmolithus. Common nannoliths include Discoaster and Sphenolithus. In addition, we picked populations of the holococcolith Zygrhablithus. For each genus a population of 15 to 20 specimens was picked together with individual specimens of Discoaster. Samples from the Walvis Ridge were measured using a Cameca IMS3f secondary ion mass spectrometer (SIMS), and analyses of replicate populations of $\mathrm{Chi}$ asmolithus and Toweius coccoliths from the same sample yield $\mathrm{Sr} / \mathrm{Ca}$ which differ by $8 \%$ and $1 \%$ respectively. Samples from Shatsky Rise were measured using a Cameca 1280 secondary ion mass spectrometer (SIMS), since the IMS3f had been decommissioned and reproducibility of replicate populations yield $\mathrm{Sr} / \mathrm{Ca}$ for Toweius which differ by $9 \%$. Both instruments are located at the Northeast National Ion Microprobe Facility at Woods Hole Oceanographic Institute.

For a more complete characterization of the variability of diagenesis during ETM2 and immediately preceding and following interval in the Walvis Ridge sediments, we also measured $\mathrm{Sr} / \mathrm{Ca}$ in various nannofossil size fractions separated from bulk sediments. The combination of $\mathrm{Sr} / \mathrm{Ca}$ results obtained by ion probe for individual taxa and in nannofossil size fractions by ICP-AES is fundamental for quantifying the amounts of secondary calcite present in the nannofossil size fractions. This suite of analyses allows us to determine to what extent diagenetic processes have biased the $\mathrm{Sr} / \mathrm{Ca}$ productivity trends in sediments covering the ETM2 


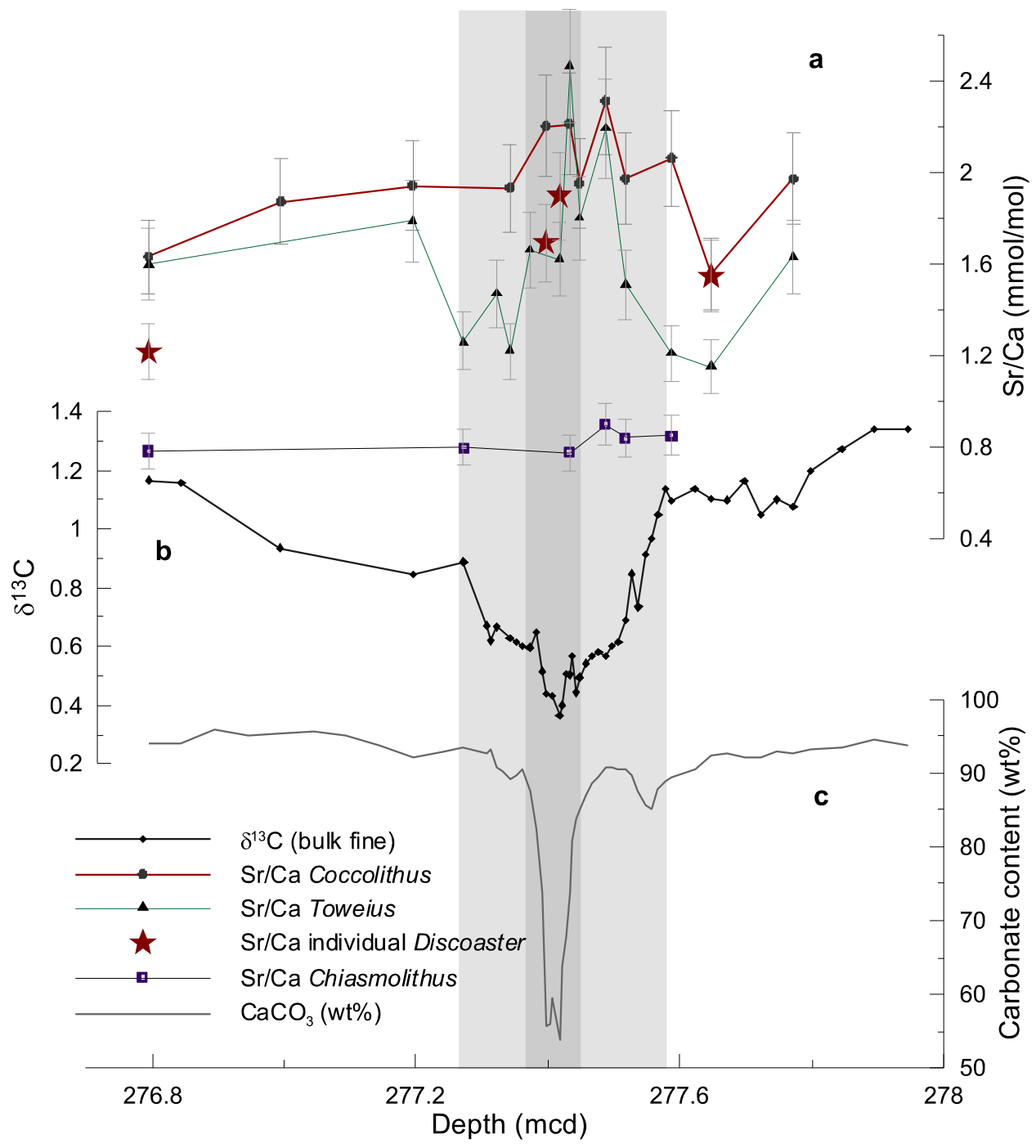

Fig. 3. (a) Sr/Ca productivity trend measured by ion probe in picked individuals or populations in correlation with the $\delta^{13} \mathrm{C}$ (Dedert et al., 2012a) across ETM2, Site 1265. Coccolithus pelagicus (grey dots), Toweius (black triangles), Discoaster (red stars), and Chiasmolithus (purple squares), (b) the carbonate content across the ETM2 interval, (c) the sediment carbonate content. Light grey bar indicates the CIE, dark grey bar marks the Elmo horizon.

interval. Size fractions were obtained through a combination of separation methods as described by Minoletti et al. (2001) and Stoll and Ziveri (2002). The application of the filtration technique as described by Minoletti et al. (2001) to bulk sediments resulted in the following size fractions: bulk fine $(<20 \mu \mathrm{m}), 10-20 \mu \mathrm{m}$ and 5-8 $\mu \mathrm{m}$. Further separation of the $10-20 \mu \mathrm{m}$ size fraction using the repeated settling/decanting technique described in Stoll and Ziveri (2002) resulted in a discoaster fraction, to which Discoaster is the dominant contributor to the carbonate (see Plate 1). Size fraction $\mathrm{Sr} / \mathrm{Ca}$ was measured using the simultaneous dual ICP-AES (Thermo ICAP DUO 6300) at the University of Oviedo. $\mathrm{Sr} / \mathrm{Ca}$ measurements were made using radial detection of $\mathrm{Sr}$ $421.5 \mathrm{~nm}$ and $\mathrm{Ca} 315 \mathrm{~nm}$. Calibration was conducted using three standards with constant $\mathrm{Ca}$ concentrations and different $\mathrm{Sr} / \mathrm{Ca}$, which vary from 0.75 to $4 \mathrm{mmol} \mathrm{mol}^{-1}$, following the intensity ratio method described by Villiers et al. (2002).

To better evaluate the long-term context for productivity change at the Walvis Ridge site, we analyzed via ICPAES the $\mathrm{Sr} / \mathrm{Ca}$ of the integral coccolith fraction $(<20 \mu \mathrm{m})$ throughout the $200 \mathrm{ka}$ interval containing the ETM2. In this broader interval, the $\mathrm{CaCO}_{3}$ content in bulk sediments is used as an indicator of variability of diagenetic overgrowth to evaluate the primary vs. secondary nature of the $\mathrm{Sr} / \mathrm{Ca}$ trends. Analytical methods for bulk carbonate $\mathrm{Sr} / \mathrm{Ca}$ by ICPAES was identical to that for the size fractions. These analyses were further supplemented by SEM images, in order to qualitatively assess changes in the degree of overgrowth. 


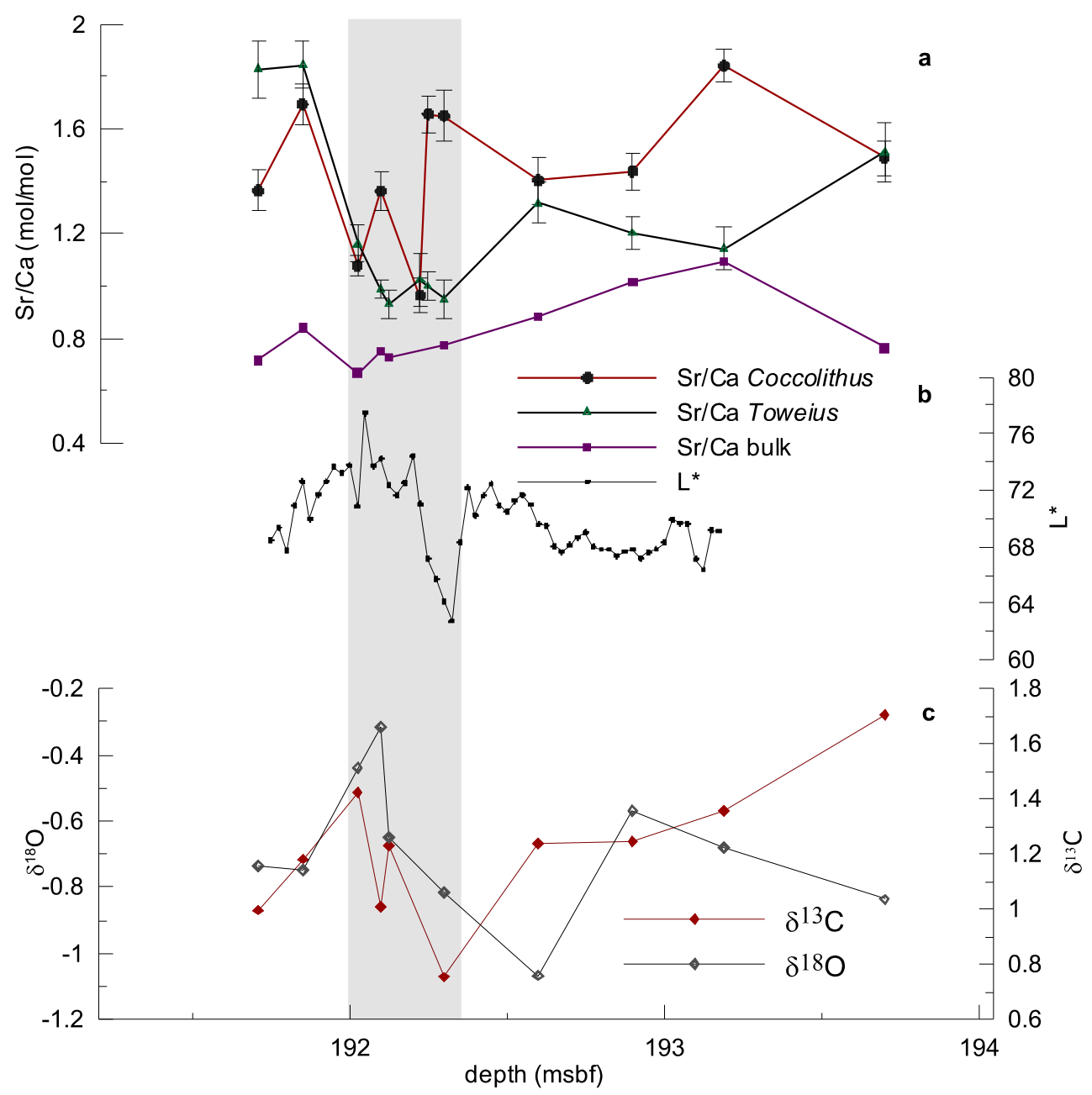

Fig. 4. (a) Sr/Ca measured in picked populations of Coccolithus and Toweius, and in bulk sediments covering ETM2 at Site 1209, (b) the $\mathrm{L}^{*}$ lightness factor; color reflectance parameter that is an indicator of carbonate content (Bralower et al., 2002a), (c) the $\delta^{13} \mathrm{C}$ and $\delta^{18} \mathrm{O}$ measured in bulk carbonate. Grey bar marks the CIE.

Nannofossil assemblages and size fractions were analyzed by a polarized light microscope (LM) at 1600 magnification and SEM at the Free University Amsterdam and the Natural History Museum London. For relative abundance counts, samples were taken every $\mathrm{cm}$ from $14 \mathrm{~cm}$ below (277, $59 \mathrm{mcd})$ the ETM2 horizon to $11 \mathrm{~cm}$ above $(277,27 \mathrm{mcd})$ the horizon and every five $\mathrm{cm}$ outside this interval. Smear slides were prepared using standard techniques. The nannofossils were identified to genus level; about 300-400 specimens were counted per interval.

\subsection{Results}

\subsection{Nannofossil preservation as assessed by SEM}

SEM analyses revealed significant contrasts in nannofossil preservation in intervals of high $\mathrm{CaCO}_{3}$ compared to intervals with strong dissolution and low $\mathrm{CaCO}_{3}$. In sedi- ments of high $\mathrm{CaCO}_{3}$, severe overgrowths cover the nannoliths Discoaster and Tribrachiatus, and the holococcolith Zygrhablithus, whereas the placoliths of Coccolithus, Chiasmolithus and Toweius are not significantly overgrown, and generally not strongly etched or fragmented (Plate 1). In the sediments of low $\mathrm{CaCO}_{3}$ of the Elmo horizon, the degree of overgrowth on Discoaster and Tribrachiatus, and Zygrhablithus decreases. With decreasing carbonate content, the liths of placolith taxa are increasingly etched and fragmented.

\section{4 $\mathrm{Sr} / \mathrm{Ca}$ in calcareous nannofossils}

\subsubsection{Ion probe $\mathrm{Sr} / \mathrm{Ca}$ determination in picked populations}

At Site 1265 , the $\mathrm{Sr} / \mathrm{Ca}$ in picked populations of both $\mathrm{Coc}$ colithus and Toweius displays an initial decrease prior to the 

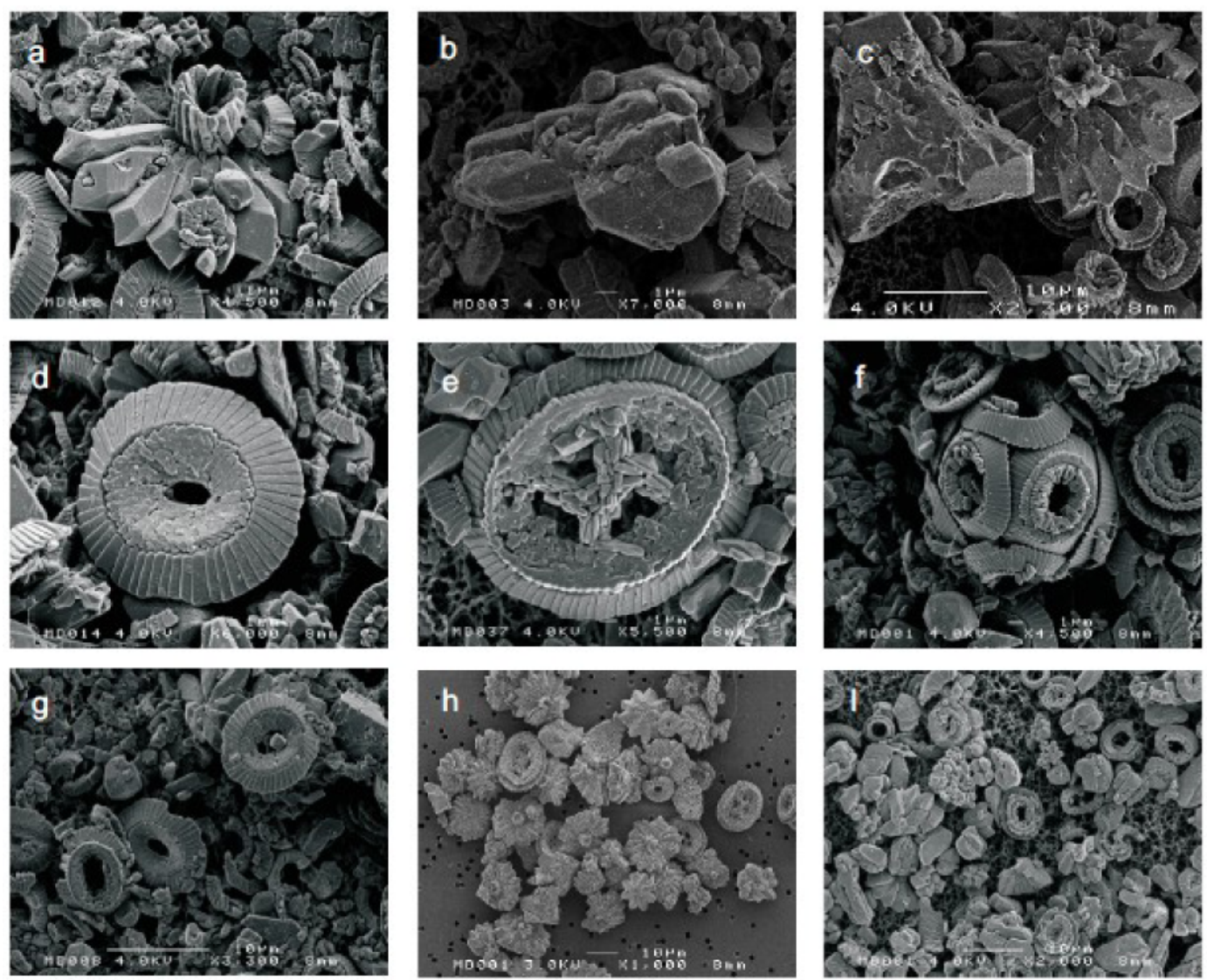

Plate 1. (a) An overgrown Discoaster, (b) an overgrown Zygrhablithus, (c) an overgrown Discoaster and Tribrachiatus, (b) a placolith of Coccolithus pelagicus, (e) a placolith of Chiasmolithus, (f) a coccosphere of Toweius, (g) an original nannofossil assemblage, (h) a separated Discoaster fraction, (i) a 5-8 $\mu \mathrm{m}$ size fraction.

ETM2 interval (Fig. 3a), which is followed by a return to former $\mathrm{Sr} / \mathrm{Ca}$ in Coccolithus a few centimeters below the onset of the CIE (Fig. 3b; as measured in the fine bulk fraction $(<20 \mu \mathrm{m}))$. The $\mathrm{Sr} / \mathrm{Ca}$ in Toweius increases at the onset of the CIE (Fig. 3a). Within the Elmo horizon, the $\mathrm{Sr} / \mathrm{Ca}$ in Coccolithus and Toweius yield higher values by $\sim 13$ and $21 \%$, respectively, compared to maximum values before and after the event. During the recovery period, the $\mathrm{Sr} / \mathrm{Ca}$ in Coccolithus remains stable until the $\mathrm{C}$ - isotope signal has returned to preETM2 values. The $\mathrm{Sr} / \mathrm{Ca}$ in Toweius drops to a second minimum comparable to the low $\mathrm{Sr} / \mathrm{Ca}$ in Toweius preceding the event, followed by a return to the initial pre-excursion values during the recovery period (Fig. 3a). Chiasmolithus does not show a significant response in the ETM2 interval, except for a small increase prior to the Elmo horizon that coincides with the increase in Coccolithus and Toweius. High $\mathrm{Sr} / \mathrm{Ca}$ in Coccolithus, Toweius and Chiasmolithus corresponds with light ${ }^{13} \mathrm{C}$-values measured below and in the Elmo horizon (Fig. 3a). The $\mathrm{Sr} / \mathrm{Ca}$ values measured by ion probe show no correlation with changes in carbonate content across the ETM2 interval (Fig. 3c).
Accurate measurements of the $\mathrm{Sr} / \mathrm{Ca}$ in picked populations of Discoaster or Zygrhablithus were not possible, due to the amount of overgrowth present on the nannoliths. In Discoaster specimens that were picked individually, the $\mathrm{Sr} / \mathrm{Ca}$ could be measured by gradually ablating through the layers of overgrowth. The $\mathrm{Sr} / \mathrm{Ca}$ measured in individual specimens of Discoaster is higher in the two specimens present in the Elmo horizon, compared to the $\mathrm{Sr} / \mathrm{Ca}$ measured in individual specimen below and above the ETM2 (Fig. 3a). No individual specimens of Zygrhablithus were picked.

At Site 1209, a CIE, with double minima of about $1 \%$, is identified in low resolution bulk $\delta^{13} \mathrm{C}$ records (Fig. 4b). $\mathrm{The} \mathrm{Sr} / \mathrm{Ca}$ in picked populations of Coccolithus and Toweius demonstrates a significant decrease in $\mathrm{Sr} / \mathrm{Ca}$ during the CIE (Fig. 4a).

\subsection{2 $\mathrm{Sr} / \mathrm{Ca}$ in different size fractions}

The applied separation techniques resulted in various size fractions with distinctly different species composition. The bulk fine fraction $(<20 \mu \mathrm{m})$ represents the original assemblage composition, whereas the application of separation 


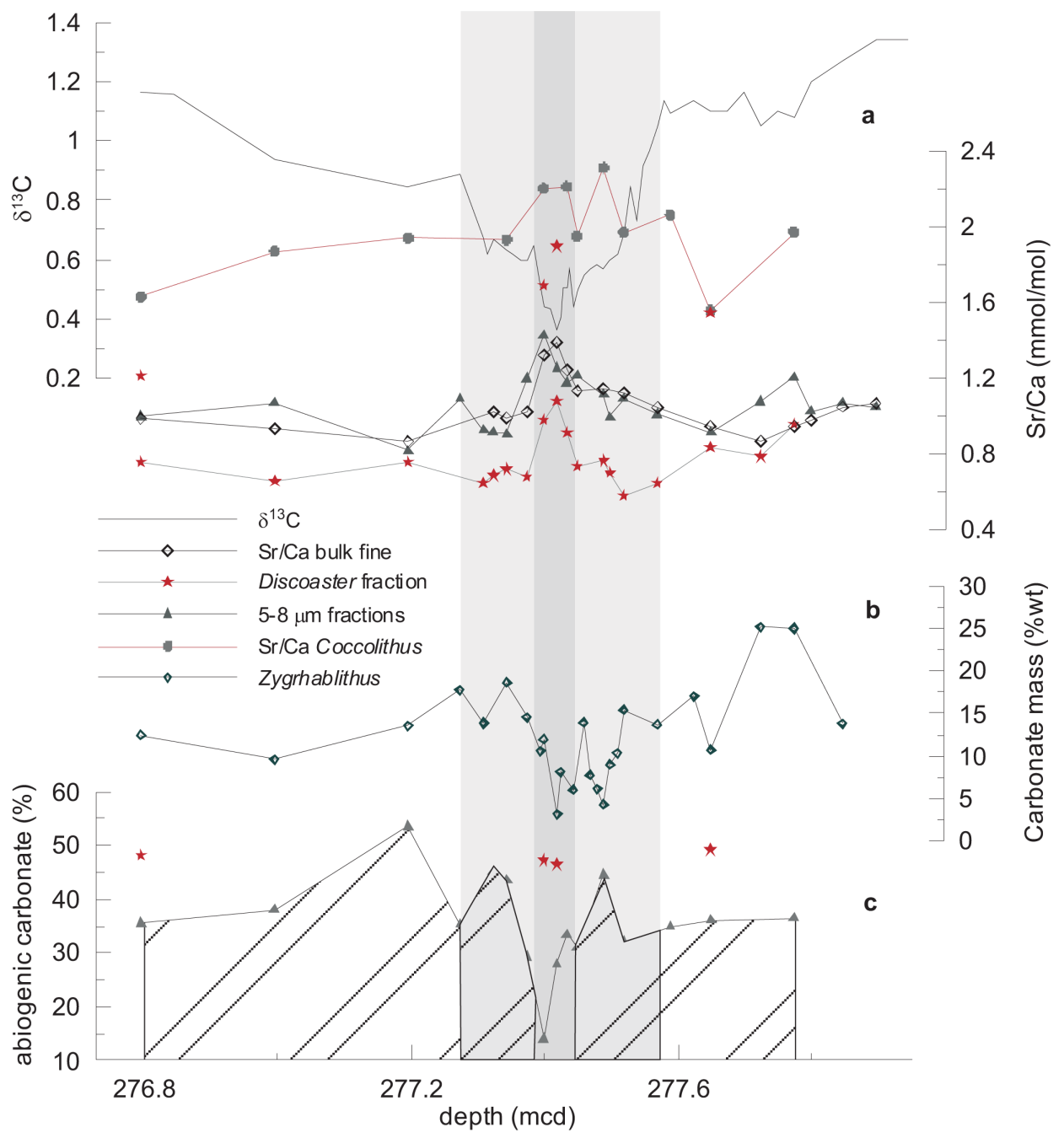

Fig. 5. (a) The $\mathrm{Sr} / \mathrm{Ca}$ measured by ion probe in Coccolithus versus the $\mathrm{Sr} / \mathrm{Ca}$ measured in the size fractions in correlation to the $\delta^{13} \mathrm{C}$, (b) the mass contribution by Zygrhablithus to the 5-8 $\mu \mathrm{m}$ size fractions, and (c) the contribution of abiogenic calcite to the discoaster and 5-8 $\mu \mathrm{m}$ size fractions. Grey bar represents the Elmo horizon, light-grey bars the CIE.

techniques resulted in a discoaster fraction to which discoasters contribute $\sim 60 \%$ of the carbonate mass (see Plate 1 ). The carbonate mass contribution to the $5-8 \mu \mathrm{m}$ size fraction is dominated by small morphotypes of mostly placoliths $(\sim 60-80 \%)$ together with a significant contribution (10$25 \%$ ) by Zygrhablithus (Fig. 5b), except for samples within the Elmo horizon, when small nannoliths of Discoaster become a major contributor.

The various $\mathrm{Sr} / \mathrm{Ca}$ profiles based on different size fractions follow the $\mathrm{Sr} / \mathrm{Ca}$ trends as measured in Coccolithus and Toweius via ion probe, although values are generally lower. The $\mathrm{Sr} / \mathrm{Ca}$ in the discoaster fraction decreases at the onset of the CIE (Fig. 5a). The abiogenic carbonate calculations show that, on average, the contribution of abiogenic calcite to the $5-8 \mu \mathrm{m}$ fractions is $\sim 30 \%$, whereas the contribution to the discoaster fraction is $\sim 50 \%$. The contribution of abio- genic calcite to the 5-8 $\mu \mathrm{m}$ size fraction decreases sharply in the Elmo horizon, whereas contribution of overgrowth to the discoaster fraction remains $\sim 50 \%$. Furthermore, abiogenic calcite appears to increase just below and above the Elmo horizon in the 5-8 $\mu \mathrm{m}$ size fraction (Fig. 5c). At Site 1209, the bulk $\mathrm{Sr} / \mathrm{Ca}$ is generally lower than the $\mathrm{Sr} / \mathrm{Ca}$ measured in picked populations, comparable to bulk $\mathrm{Sr} / \mathrm{Ca}$ values for Site 1265 (Fig. 4a).

\subsubsection{Long-term $\mathrm{Sr} / \mathrm{Ca}$ trends in bulk fine sediments}

Long-term trends in $\mathrm{Sr} / \mathrm{Ca}$ measured in bulk fine $(<20 \mu \mathrm{m})$ sediments reveal a cyclic forcing over a $\sim 200 \mathrm{ka}$ time interval, although $\mathrm{Sr} / \mathrm{Ca}$ trends are less salient in proximity of the ETM2 interval (cycle numbers one, two and five; orbitallydriven cycles in $\delta^{13} \mathrm{C}$ and carbonate content cycles identified 


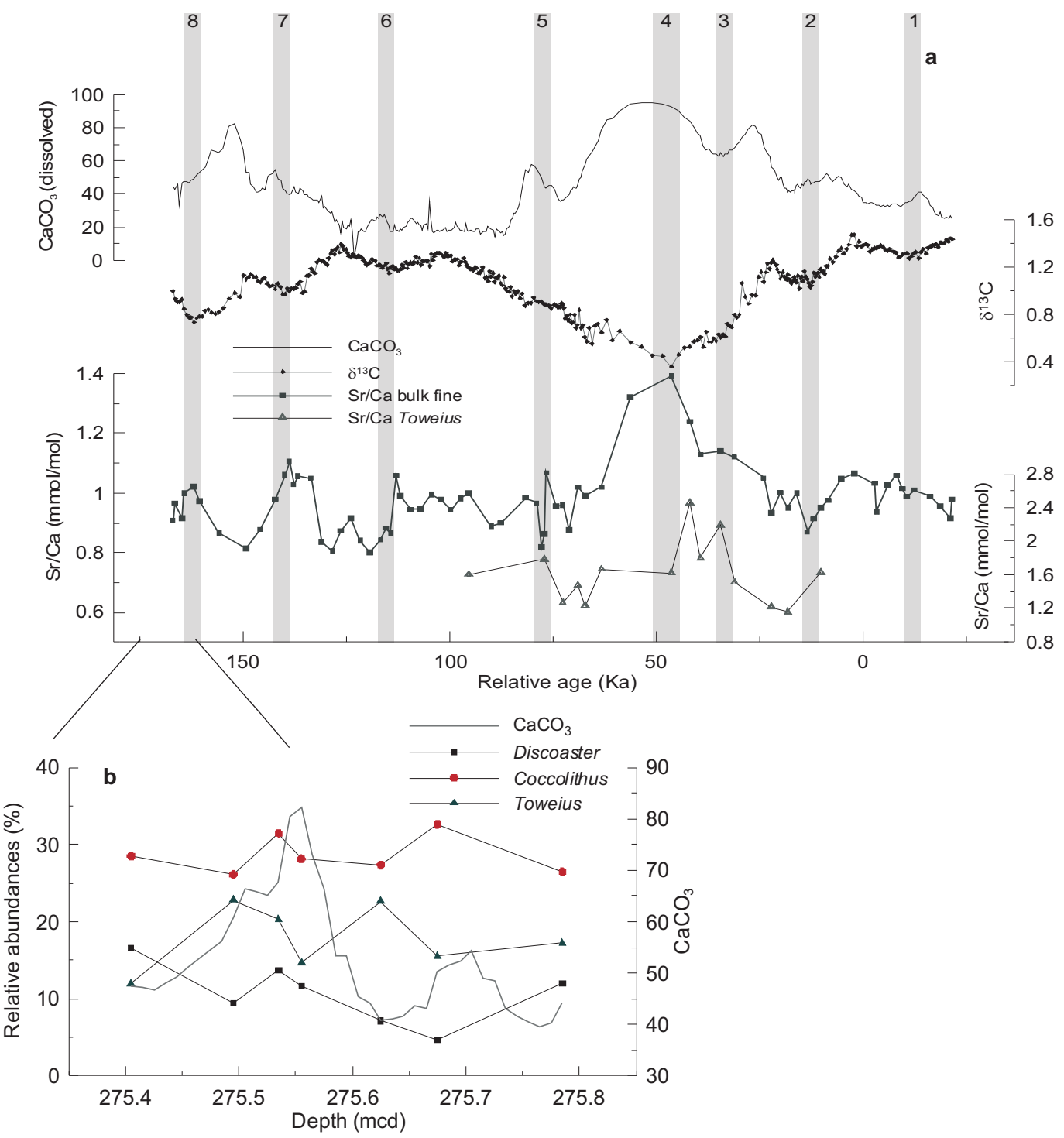

Fig. 6. (a) Long-term $\mathrm{Sr} / \mathrm{Ca}$ productivity record measured in bulk fine sediments and $\mathrm{Sr} / \mathrm{Ca}$ measured by ion probe in Toweius, in correlation to the calculated dissolved carbonate (Stap et al., 2009) and bulk $\delta^{13} \mathrm{C}$ (Stap et al., 2009). Grey bars represent precessional cycles as identified by Stap et al. (2009), (b) the changes in assemblage composition across the H2 event.

by Stap et al., 2009; Fig. 6a). Bulk fine $\mathrm{Sr} / \mathrm{Ca}$ shows no direct correlation with the carbonate dissolution as calculated by Stap et al. (2009) (Fig. 6a), except for the $\mathrm{Sr} / \mathrm{Ca}$ values measured in bulk fine sediments from within the Elmo horizon that show a substantial increase compared to other cyclic peaks in productivity. The clearest cyclic-driven increase in $\mathrm{Sr} / \mathrm{Ca}$ is recorded following ETM2 during cycles number seven and eight, with a difference between minima and maxima in $\mathrm{Sr} / \mathrm{Ca}$ of $\sim 23 \%$. An interval of relatively high $\mathrm{Sr} / \mathrm{Ca}$ is present between cycle five and six (Fig. 6a). Longterm $\mathrm{Sr} / \mathrm{Ca}$ trends measured in the bulk fine sediments do not show a clear correlation with the $\mathrm{Sr} / \mathrm{Ca}$ ion probe record in the proximity of ETM2.

\subsection{Changes in nannofossil abundances}

The relative abundances of the different nannofossil taxa show pronounced changes within the dissolution interval (Fig. 7), e.g. a sharp increase of the dissolution-resistant Discoaster and a drop in Toweius abundance that is strongly correlated to the CIE (Fig. 7; Dedert et al., 2012a). Abundances of Chiasmolithus decrease during ETM2. The relative abundances of the most abundant nannofossil in the assemblages, Coccolithus, show a sharp increase within the CIE $\sim 10 \mathrm{ka}$ prior to the Elmo horizon (Fig. 7). 


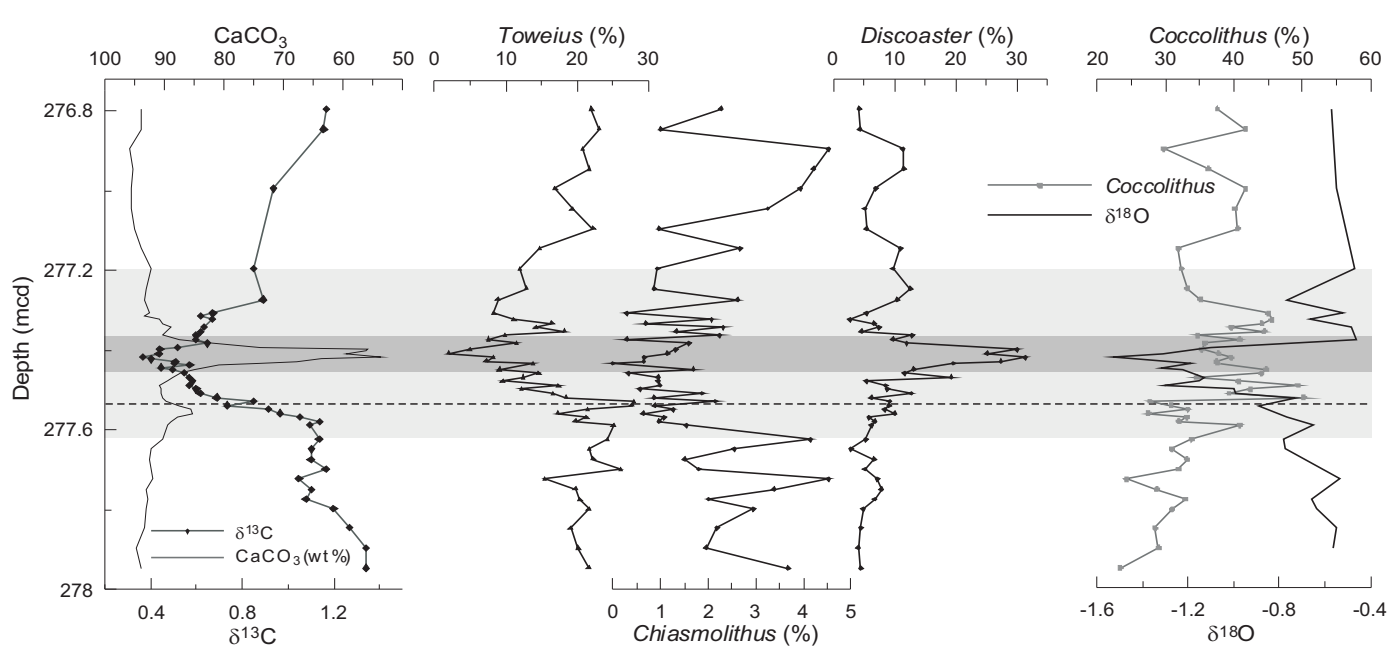

Fig. 7. The $\delta^{13} \mathrm{C}$ (black rhomboids) and the carbonate content (grey line) plotted against the relative abundances of Toweius, Discoaster, Chiasmolithus and Coccolithus pelagicus in correlation with the $\delta^{18} \mathrm{O}$ measured in the 5-8 $\mu \mathrm{m}$ size fraction (Dedert et al., 2012). Dark grey bar indicates Elmo horizon, light grey bar indicates the CIE. The interval of the salient increase in Coccolithus abundance is marked by a dashed grey line.

\subsection{Variations in degree of overgrowth during a ETM2 at Walvis Ridge}

Biogenic marine calcites precipitate more rapidly than abiogenic overgrowths, and in the case of coccoliths that form in specialized intracellular vesicles, have much higher partitioning coefficients for $\mathrm{Sr}$ than abiogenic diagenetic calcites. Abiogenic calcite overgrowths therefore have lower values that the $\mathrm{Sr} / \mathrm{Ca}$ of nannofossils, a feature that has long been exploited in studies of diagenesis (Richter and Liang, 1993). We exploit this relationship to quantitatively calculate the contribution of abiogenic calcite to nannofossil sediment fractions at Walvis Ridge. We calculate the fraction of abiogenic calcite by assuming that the $\mathrm{Sr} / \mathrm{Ca}$ of separated nannofossil sediment fractions is result of mixture of an abiogenic low $\mathrm{Sr}$ endmember and high $\mathrm{Sr}$ pristine unaltered coccolith endmember. For the abiogenic endmember, we used the $\mathrm{Sr} / \mathrm{Ca}$ value of 0.13 that was measured in abiogenic needles found at Site 1209 (Stoll et al., 2007c). These needles are the most readily isolatable material to analyze, and we believe they are representative of the nature of secondary overgrowth forming during the earliest Eocene, because the sharp changes in their abundance and correlation of their abundance with the brief PETM recovery interval. This indicates they formed very near the sediment water interface, in seawater or porewaters whose composition was similar to seawater, in response to changes in bottom water saturation state. The inferred $\mathrm{Sr} / \mathrm{Ca}$ value is also consistent with endmember $\mathrm{Sr} / \mathrm{Ca}$ inferred from progressive ablation of severely overgrown Discoaster on the ion probe (Dedert et al., 2012a).
The $\mathrm{Sr} / \mathrm{Ca}$ of the pristine biogenic nannofossil endmember is an average from the ion probe determinations of $\mathrm{Sr} / \mathrm{Ca}$ of unaltered placoliths and the cores of overgrown nannoliths, weighted by the relative carbonate contributions of each of these genera to the total coccolith assemblage of the size fraction. The relative carbonate mass contribution of carbonate by liths of each genus to the total mass of a specific size fraction was calculated following Young and Ziveri (2000), with nannofossil weights per nannolith taken from Stoll and Bains (2003). The contributing data and resulting estimates of the contribution of abiogenic calcite to the $5-8 \mu \mathrm{m}$ size fraction are shown in (Fig. 8).

The contribution of abiogenic overgrowth to the 5-8 $\mu \mathrm{m}$ size fraction ranges from $\sim 30$ to $50 \%$ and is at a minimum during the ETM2 dissolution interval (Figs. 3 and 5c). Our interpretation is that overgrowth results from bottom waters and shallow pore waters which are oversaturated with respect to $\mathrm{CaCO}_{3}$. Dissolution below the lysocline is a symptom of bottom waters which are much less saturated (in some cases undersaturated) with respect to $\mathrm{CaCO}_{3}$, and therefore much less prone to overgrowth on nannofossils. For this reason, dissolution intervals have better preservation of the primary calcite geochemical signal due to the reduced importance of secondary abiogenic calcite.

Because certain nannoliths such as Discoaster and Zygrhablithus are much more strongly overgrown than placoliths, size fractions dominated by these taxa feature more overgrowth and lower $\mathrm{Sr} / \mathrm{Ca}$ (Fig. 5). Variable abundances of these taxa can also contribute to the varying amounts of abiogenic calcite to the size fractions. One check on the robustness of our geochemical calculation of abiogenic contribution is to evaluate if the relative amount of overgrowth only from Discoaster and Zygrhablithus is sufficient to explain 


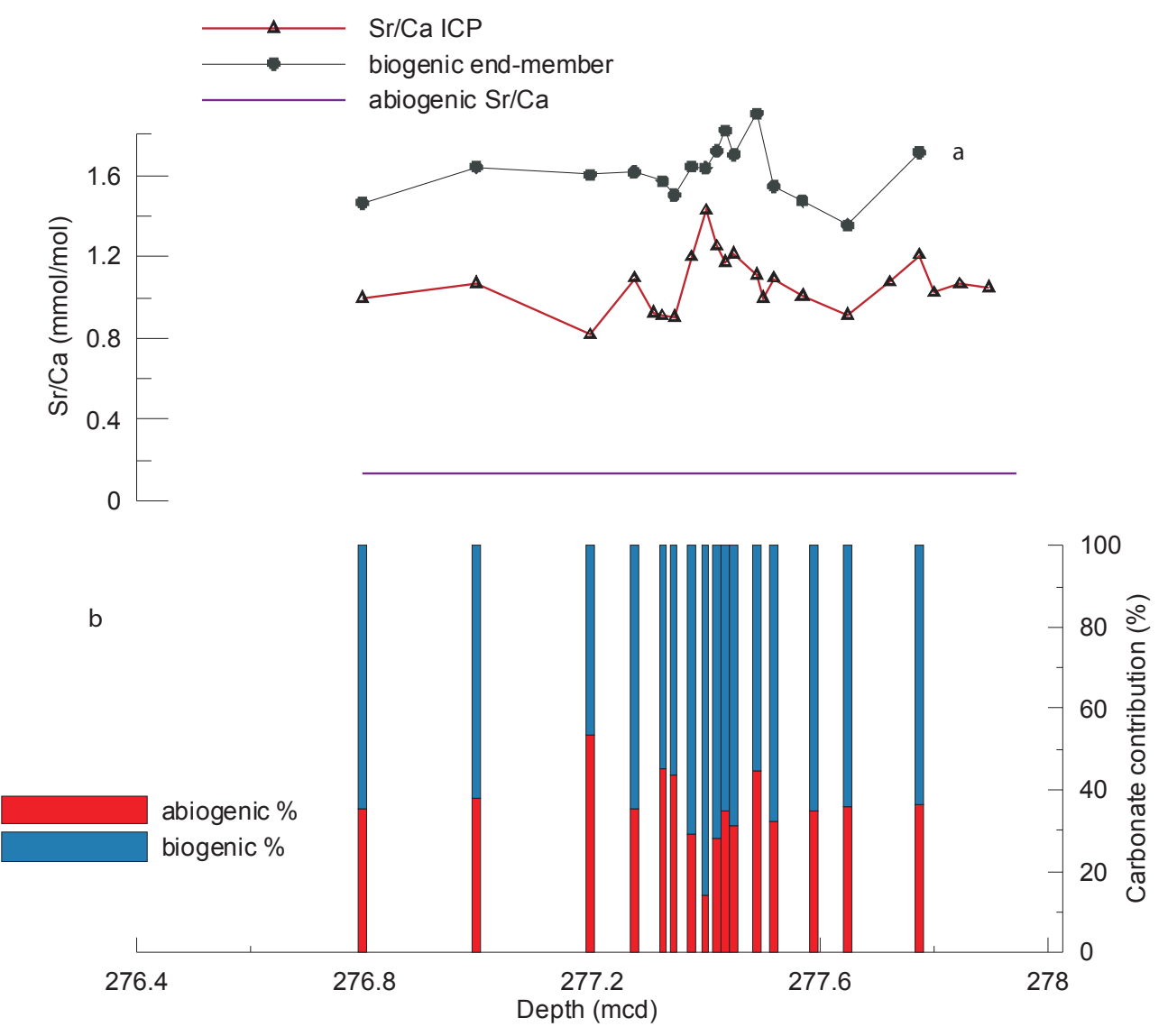

Fig. 8. (a) Plot showing the biogenic end-member calculated from ion probe values and the size fraction Sr/Ca measured by ICP, which together with the abiogenic value of 0.13 were used to calculate the abiogenic calcite contribution. (b) The abiogenic versus the biogenic calcite contribution to the carbonate that makes up the 5-8 $\mu \mathrm{m}$ size fraction, ETM2 Site 1265.

the observed abiogenic carbonate. The most heavily overgrown specimens of Discoaster and Zygrhablithus appear to be composed of as much as $50 \%$ to $70 \%$ of secondary calcite, according to SEM analysis and geochemical heterogeneity in profiles of overgrown nannoliths completed with the ion probe (Dedert et al., 2012a). The abundances of these heavily overgrown taxa account for $\sim 20$ to $40 \%$ of the carbonate mass in the 5-8 $\mu \mathrm{m}$ fraction, whereas contribution to the discoaster fraction is $\sim 70$ to $80 \%$. Consequently, the overgrowth on these taxa alone could cause $\sim 10$ to $30 \%$ abiogenic calcite to the $5-8 \mu \mathrm{m}$ fraction, and $\sim 35$ to $40 \%$ of the calcite present in the discoaster fraction coming from abiogenic overgrowth. The difference between these percentages and the geochemical estimates of overgrowth are within the error in the coccolith mass calculations by Young and Ziveri (2000). In addition to the overgrowth on Discoaster and Zygrhablithus, other sources of abiogenic calcite that further contributed to the size fractions could include small amounts of overgrowth present on placoliths and abiogenic calcite blocks. Moreover, the nannofossil size fractions include other genera of which the $\mathrm{Sr} / \mathrm{Ca}$ values are unknown from ion probe. If these lesser contributors had lower $\mathrm{Sr} / \mathrm{Ca}$ than the dominant genera, the degree of overgrowth could be overestimated. Alternatively, a systematic overestimation in the degree of secondary calcite could arise if the $\mathrm{Sr} / \mathrm{Ca}$ of the diagenetic end-member has been overestimated. Consequently, while the temporal trends and the different degrees of overgrowth in the size fractions can be inferred with confidence, the estimates of overgrowth have significant uncertainty.

Thus in sediments from the Walvis Ridge site, interpretation of $\mathrm{Sr} / \mathrm{Ca}$ in size fractions cannot assume that all variations are due to primary biogenic calcite, since variations in the abundance of abiogenic calcite also contribute. For example, the downward trend in the discoaster fraction $\mathrm{Sr} / \mathrm{Ca}$ during the onset of the CIE (Fig. 5b) appears to be due to increased abiogenic calcite to this fraction. Such an increase probably occurred during changes in post-depositional conditions accompanying the onset of the ETM2 event, i.e. shoaling of the lysocline (Lourens et al., 2005). Similarly, the higher contribution of abiogenic calcite to the $5-8 \mu \mathrm{m}$ size fractions just above and below the Elmo horizon (Fig. 5c) could have dampened the $\mathrm{Sr} / \mathrm{Ca}$ productivity trend measured in this fraction. The high 
contribution of abiogenic calcite to the discoaster fraction compared with the 5-8 $\mu \mathrm{m}$ size fraction is also evident in the $\delta^{18} \mathrm{O}$ measurements in the discoaster fraction, which were biased towards heavier $\delta^{18} \mathrm{O}$ values as a result of the abiogenic calcite (overgrowths) that precipitated in colder pore waters (Dedert et al., 2012a). Furthermore, the $\delta^{18} \mathrm{O}$ data suggest an increase in abiogenic calcite to this fraction prior to the Elmo horizon, as inferred from $\mathrm{Sr} / \mathrm{Ca}$ data. This potential for variability in the contribution of secondary overgrowth must be taken into account in the interpretation of the long-term bulk $\mathrm{Sr} / \mathrm{Ca}$ record from the Walvis Ridge Site.

Although the limited number of species analyzed by ion probe at Site 1209 precludes a quantitative calculation of the contribution of abiogenic calcite to the sediments, comparison of $\mathrm{Sr} / \mathrm{Ca}$ of the dominant placoliths with that of bulk coccolith fraction implies that there is also significant abiogenic component in the bulk coccolith fraction at this site.

\section{Discussion}

\subsection{Sr/Ca-derived primary productivity obtained by ion probe}

Several lines of evidence suggest that temporal $\mathrm{Sr} / \mathrm{Ca}$ variations observed in individually picked placolith nannofossils analyzed by ion probe are not artifacts of differential diagenesis. Firstly, SEM analyses done on all selected intervals showed that the placoliths (e.g. Coccolithus, Toweius, and Chiasmolithus) are not covered by appreciable overgrowth, which has made obtaining the $\mathrm{Sr} / \mathrm{Ca}$ in the primary calcite (core signal) by the ion probe possible. Secondly, the applied method of picking individual nannofossils enables us to selectively isolate specimens that are well-preserved, which further minimizes the possibility of contamination by abiogenic calcite. In addition, at Walvis Ridge, the difference in $\mathrm{Sr} / \mathrm{Ca}$ response in the four species shows that dissolution, which is common to all sediment components, and would manifest itself through comparable variations in $\mathrm{Sr} / \mathrm{Ca}$ across the event if overgrowths contributed significantly to the mass of these coccoliths, has not been the dominant control on temporal variations in the coccolith $\mathrm{Sr} / \mathrm{Ca}$ obtained by ion probe. For example, in the Walvis Ridge records, variations in $\mathrm{Sr} / \mathrm{Ca}$ in Coccolithus preceding the onset of dissolution (Fig. 3a, c) differ from the $\mathrm{Sr} / \mathrm{Ca}$ in Toweius, indicating that these $\mathrm{Sr} / \mathrm{Ca}$ values are not the result of diagenetic processes, as for example could be expected in the Elmo horizon as a result of reduced presence of overgrowth. Similarly, while the two genera analyzed at Shatsky Rise exhibit similar temporal trends in $\mathrm{Sr} / \mathrm{Ca}$, the trend in $\mathrm{Sr} / \mathrm{Ca}$ is opposite to what would be expected from variable overgrowth because the minima in $\mathrm{Sr} / \mathrm{Ca}$ occur during the dissolution interval when overgrowth is reduced.

The effect of temperature variations on placolith $\mathrm{Sr} / \mathrm{Ca}$ values is minor during ETM2. The $\delta^{18} \mathrm{O}$ in benthic and plank- tonic foraminifera during ETM2 (Site 1265) shows a $\sim 2$ $4{ }^{\circ} \mathrm{C}$ increase (Stap et al., 2010a). This implies that at Walvis Ridge, $4-8 \%$ of the 13 to $21 \% \mathrm{Sr} / \mathrm{Ca}$ increase in Coccolithus and Toweius, respectively, could be attributed to temperature. At Shatsky Rise, placolith $\mathrm{Sr} / \mathrm{Ca}$ decrease in spite of the potential 4-8\% increase in $\mathrm{Sr} / \mathrm{Ca}$ due to warming. The $\mathrm{Sr} / \mathrm{Ca}$ trends by the probed taxa across ETM2 at Walvis Ridge also show no correlation with temperature trends as inferred from $\delta^{18} \mathrm{O}$ (Fig. 7). Thus, we deduce that the principal temporal trends in $\mathrm{Sr} / \mathrm{Ca}$ in the placolith genera analyzed by ion probe are due to changes in the productivity of these genera in Eocene surface waters.

Because the ion probe geochemical data appear minimally affected by diagenesis, we infer the overall pattern of productivity and ecological change from the $\mathrm{Sr} / \mathrm{Ca}$ variations in the dominant genera of the sediments, Coccolithus and Toweius, since these two genera exhibit similar overall temporal trends in our record, consistent with the similarities in their ecological preferences. At Site 1265, there is a clear background variation in productivity by both Coccolithus and Toweius of $\sim 20$ to $30 \%$, respectively, prior to the first C-isotopic shift that marks the ETM2 (with a maximum at $277.75 \mathrm{mcd}$ and minimum at $277.65 \mathrm{mcd}$ ) (Fig. 3b). The decrease in $\mathrm{Sr} / \mathrm{Ca}$ prior to ETM2 measured in both species suggests that nutrient availability temporarily decreased, and the transient increase of $\mathrm{Sr} / \mathrm{Ca}$ in both taxa just prior to the carbon isotopic excursion is thus likely to be a return to the initial productivity rates rather than a "precursor" related to environmental conditions during ETM2. During the initial recovery, the minima in $\mathrm{Sr} / \mathrm{Ca}$ in Toweius may also reflect the same cyclic forcing of productivity observed prior to the ETM2 event.

The productivity responses of minor species are less salient. For Chiasmolithus, a single sample potentially indicates a slightly higher productivity in this genus during the ETM2 onset (Fig. 3a). The SEM analyses showed that nannofossil specimens of Chiasmolithus are not significantly overgrown, implying that the productivity signal obtained from the $\mathrm{Sr} / \mathrm{Ca}$ analyses is a genuine productivity response of Chiasmolithus. Similar transient increases in Chiasmolithus productivity at the onset of hyperthermal events have been observed for the PETM in the Southern Ocean ODP Site 690 (Stoll et al., 2007c), and in the South Atlantic at Walvis Ridge ODP Site 1263 (Dedert et al., 2012b). The brief, transient response may reflect that Chiasmolithus is a species that is better adapted to mesotrophic cold- water environments (Bralower, 2002b), and the environmental conditions attained at the peak ETM2 conditions at Site 1265 may not have been favorable for an optimal growth of this taxon. Mutterlose et al. (2007) found that Chiasmolithus did not change much in abundance at Site 1260 during the PETM, suggesting limited environmental sensitivity of this genus at this equatorial site.

Interpretation of $\mathrm{Sr} / \mathrm{Ca}$ in discoasters is, in addition to the high degree of secondary overgrowth on this taxon, further complicated by the small number of individuals represented 
by the analyses, since individual liths rather than populations were analyzed. Two individual discoasters during the ETM2 event, present in the Elmo horizon (Fig. 3a, c), feature higher core $\mathrm{Sr} / \mathrm{Ca}$ (Dedert et al., 2012a), which could be interpreted as nutrient-stimulation of productivity in this genera, as observed for Coccolithus and Toweius. However, the SEM images and geochemical data presented in that study suggest that discoasters are strongly overgrown with secondary calcite. If secondary overgrowth on discoasters was reduced during the ETM2 event (i.e. within the Elmo horizon), then the greater prevalence of primary high $\mathrm{Sr} / \mathrm{Ca}$ calcite may have elevated the $\mathrm{Sr} / \mathrm{Ca}$. Thus it is not possible to confidently interpret productivity variations of Discoaster at this location.

In contrast to Site 1265 , the $\mathrm{Sr} / \mathrm{Ca}$ productivity record for Coccolithus and Toweius shows a profound decrease in $\mathrm{Sr} / \mathrm{Ca}$ at Site 1209 (Fig. 4). As prevailing environmental conditions are very different from Site 1265, i.e. open ocean environment versus upwelling region, nutrient regimes would have had a fundamentally different influence on phytoplankton.

\subsection{A longer term context for ETM2 productivity variations from the bulk fine $\mathrm{Sr} / \mathrm{Ca}$ record}

Unlike the ion probe $\mathrm{Sr} / \mathrm{Ca}$ record based on picked monogeneric populations, the $\mathrm{Sr} / \mathrm{Ca}$ record of the bulk coccolith fraction from Walvis Ridge may be influenced by variations in species assemblage composition and variations in the degree of secondary calcite overgrowth. For one of the cycles in bulk $\mathrm{Sr} / \mathrm{Ca}$ after the ETM2, known as H2 (Stap et al., 2009), we completed nannofossil assemblage counts and find that the species composition does not change significantly (Fig. 6b). Thus $\mathrm{Sr} / \mathrm{Ca}$ cycles are not caused by changes in assemblage composition. Changes in $\mathrm{Sr} / \mathrm{Ca}$ due to variations in the degree of overgrowth are likely to be most pronounced across the strong transitions in $\mathrm{CaCO}_{3}$ content through the ETM2 interval, as our calculations of the \% abiogenic carbonate in size fraction indicated. The peak in $\mathrm{Sr} / \mathrm{Ca}$ measured during ETM2 strongly correlates with the dissolution interval, and likely results from the reduced abundance of abiogenic overgrowth during this time interval when bottom waters were less oversaturated (or undersaturated). This maximum in $\mathrm{Sr} / \mathrm{Ca}$ therefore should not be interpreted as a unique, anomalously high productivity interval but rather one of minimum diagenetic overgrowth. Other maxima in $\mathrm{Sr} / \mathrm{Ca}$, however, show no consistent relationship with $\mathrm{CaCO}_{3}$ content or estimated dissolution intensity. We interpret these $\mathrm{Sr} / \mathrm{Ca}$ variations, especially well-developed during cycles number seven and eight (Fig. 6a), to represent productivity variations in response to a background forcing during time intervals other than ETM2. Accordingly, background productivity variation corresponding to $\mathrm{Sr} / \mathrm{Ca}$ changes of about $23 \%$, may have been typical of the Early Eocene at Walvis Ridge.

\subsection{Climatic reconstructions using nannofossil assemblages: dissolution versus paleoecology}

The response of calcareous nannoplankton to hyperthermal events in the geological past is especially difficult to reconstruct using census counts, since these events are often accompanied by a pronounced dissolution of the calcareous components. During ETM2 at Site 1265, the drop in $\mathrm{CaCO}_{3}$ $\%$ from $\sim 90 \%$ to $\sim 53 \%$ signifies a loss of about $70 \%$ of the original carbonate content (Broecker, 2003) to a loss of $\sim 90 \%$ as calculated by Stap et al. (2009). The high concentration of fragments of placoliths present in the nannofossil assemblages indicate that dissolution has had a major impact on the abundances of particularly these more solution-prone placolith genera (Perch-Nielsen, 1985).

For ETM2 at Site 1265, concomitant with the CIE and more importantly the Elmo horizon, variations in relative abundances of several nannofossil taxa show a marked change, most notably a sharp increase in Discoaster and decreases in Toweius (Fig. 7; Dedert et al., 2012a). These changes are generally inferred to result from the warmer and more oligotrophic conditions. Such climatic changes have also been inferred from the Chiasmolithus abundance patterns (Jiang and Wise, 2009). However, there is increasing recognition of a strong and potentially dominant control of selective dissolution (Raffi and deBernardi, 2008; Jiang and Wise, 2009), and the pronounced changes and strong correlation with sediment carbonate content and CIE suggest dissolution significantly affected nannofossil assemblage composition at this site.

Although selective dissolution may influence the relative abundances of the various placolith species during ETM2, in some cases there is clear evidence for primary ecological shifts. An increase in Coccolithus prior to the dissolution interval, when carbonate content was still $\sim 90 \%$, is likely to reflect a real shift in photic zone ecology. Coccolithus is generally regarded to be a warm-water species (Aubry, 1998) with high abundance in eutrophic settings (Jiang and Wise, 2006). Thus, this increase would suggest more eutrophic conditions to prevail prior to ETM2. A comparable increase in eutrophic species just prior to the PETM was observed during several studies (Bralower, 2002b; Tremolada and Bralower, 2004; Jiang and Wise, 2006). In one such study in the Weddell Sea, an increased abundance of the eutrophic taxon Biscutum just before the PETM correlates to a warming signal found in the O-isotopes (Bralower, $2002 b$ ), which is ascribed to a possible pulse of increased upwelling. A similar correlation is found between increasing relative abundances of Coccolithus and the transient warming found in the O-isotopes prior to the Elmo horizon when $\mathrm{CaCO}_{3}$ was still $\sim 90 \%$ (Fig. 7). These correlations may result from slightly better preservation, but more likely suggest a resilience of this taxon to environmental conditions during ETM2. As such, the abundance trends in Coccolithus imply 
an overall sustained productivity of this eutrophic genus just prior to the event, similarly to the $\mathrm{Sr} / \mathrm{Ca}$ productivity signal for this taxon.

\subsection{Mechanisms for stimulating productivity and relationships to climate feedbacks}

The amplitude of change in $\mathrm{Sr} / \mathrm{Ca}$ measured in the dominant genera Coccolithus and Toweius show considerable variations at the Walvis Ridge both during ETM2 and over the $200 \mathrm{ka}$ interval prior to and following ETM2. This suggests that at this site, the productivity in response to ETM2 was predominantly controlled by a cyclic forcing, and not by changes in environmental conditions related to the event. Nutrient concentrations at the Walvis Ridge during ETM2 are likely to have mainly been affected by changes in upwelling intensity perhaps due to orbital forcing of wind intensity or front positions (Sloan and Huber, 2001). Precessional forcing is a dominant factor in controlling the intensity and zonality of the trade winds, which in turn affects upwelling intensity. Wind intensity determines the degree of transport of cold upwelled water in filaments over the Walvis Ridge (West et al., 2004), with stronger upwelling occurring during precession maxima resulting from stronger SE trade winds. Trade wind modulated productivity in this region of the South Atlantic has been observed for the Quaternary (Schneider et al., 1996; Jahn et al., 2003). Furthermore, extant coccolithophore assemblages in the Southwestern African margin, similar to other upwelling regions, are largely governed by changes in upwelling intensity (Boeckel and Baumann, 2004; Ziveri et al., 1995; Ziveri and Thunell, 2000). However, modeling studies are not conclusive about whether wind strength would have intensified during hyperthermal events (Huber and Sloan, 1999, 2000, 2001; Sloan and Huber, 2001). While increased weathering is another mechanism that has been recognized as a potentially important source of nutrients to the ocean during the PETM (Bowen et al., 2004), a similar effect cannot be uniquely inferred from productivity patterns at our two locations during ETM2.

In contrast, productivity at the open ocean Site 1209 demonstrates a significant decrease during ETM2, unique within the time span of study. This response implies that the primary driver(s) of calcareous nannoplankton productivity are localized. Under the warm conditions of ETM2, stratification at Site 1209 could have decreased nutrient supply, and thereby lowered productivity.

The results presented here show that during the hyperthermal events of inferred higher $\mathrm{CO}_{2}$, there is no evidence of a productivity crisis of calcifying algae, consistent with a number of studies on the PETM (Gibbs et al., 2006a; Stoll et al., 2007c). Although studies have suggested an increase in photosynthesis and a decrease in calcification under elevated $\mathrm{CO}_{2}$ concentrations (i.e. decrease in $\left[\mathrm{CO}_{3}^{2-}\right]$ ) (Sciandra et al., 2003; Delille et al., 2005), other studies highlighted the importance of species-specific and strain-specific responses to high $\mathrm{CO}_{2}$ conditions on calcification (Langer et al., 2006, 2009; Beaufort et al., 2011). The rate of $\mathrm{CO}_{2}$ addition during ETM2 is still not well established but may have occurred over the course of $\leq 20 \mathrm{ka}$ (Stap et al., 2010b). Therefore, the degree of surface ocean acidification may have been negligible if $\mathrm{CO}_{2}$ release happened in $>10 \mathrm{ka}$, since the $\mathrm{pH}$ and carbonate saturation state will be regulated by the ability of the ocean and sediments to stabilize ocean chemistry and atmospheric $\mathrm{CO}_{2}$ through carbonate compensation (Ridgwell and Zeebe, 2005; Ridgwell and Schmidt, 2010).

\section{Summary}

The calcareous nannoplankton productivity, as reconstructed from ion probe $\mathrm{Sr} / \mathrm{Ca}$ measurements, indicates that at Walvis Ridge the ETM2 coincides with a productivity optimum. In contrast at ODP 1209 , ion probe $\mathrm{Sr} / \mathrm{Ca}$ data indicate decreased productivity at the ETM2, potentially due to greater stratification and reduced nutrient supply to the photic zone. At Walvis Ridge, the degree of secondary abiogenic overgrowth decreases sharply through the CIE and dissolution interval of the ETM2, inducing variations in $\mathrm{Sr} / \mathrm{Ca}$ in nannofossil size fractions. Yet, in a time interval before and after the ETM2, during periods of relatively stable carbonate dissolution intensity, bulk coccolith $\mathrm{Sr} / \mathrm{Ca}$ measurements indicate at Walvis Ridge considerable background variation in productivity, which appears to be comparable in magnitude to the ETM2 optimum. Therefore, the ETM2 did not represent a global crisis for calcifying plankton, but in the Southern Atlantic represents an interval at the high end of local productivity conditions due most likely to enhanced upwelling from altered wind strength or frontal systems.

Acknowledgements. This work was supported by the Darwin Center for Biogeosciences (MD and PZ), the National Science Foundation (NSF EAR-0628336 to HMS) and the Spanish Minister of Science and Innovation (MCINN PK122862 and AD122622). We thank Saskia Kars and Jeremy Young for SEM analyses, Claudia Agnini for taxonomic assistance, Lucy Stap and Luc Lourens for insightful discussions and close collaboration, and Gerald Ganssen and Luc Lourens for comments to an earlier version that helped to improve this manuscript.

Author contributions: this manuscript represents part of the $\mathrm{PhD}$ thesis of MD at the Free University Amsterdam (VUA) under active direction of HMS, DK and PZ. Size fraction separation and assemblage counts were completed by MD at VUA. Coccolith picking and elemental geochemistry of size fractions was completed by MD at Oviedo University under direction of HS. Shatsky Rise coccolith picking was completed by Kinuyo Kanamaru. Ion probe analyses were conducted by H. S. and N. S. with help from K. K. for Shatsky Rise samples.

Edited by: L. Beaufort 


\section{References}

Aubry, M. P.: Early Paleogene calcareous nannoplankton evolution: a tale of climatic amelioration, in: Late Paleocene Early Eocene climatic and biotic events in the marine and terrestrial records, edited by: Aubry, M. P., Lucas, S. G., and Berggren, W. A., 158203, Columbia University Press, New York, 1998.

Balch, W. M., Bowler, B. C., Drapeau, D. T., Poulton, A. J., and Holligan, P. M.: Biominerals and the vertical flux of particulate carbon from the surface ocean, Geophys. Res. Lett., 37, L22605, doi:10.1029/2010GL044640, 2010.

Barber, R. T. and Hiscock, M. R.: A rising tide lifts all phytoplankton: Growth response of other phytoplankton taxa in diatomdominated blooms, Global Biogeochem. Cy., 20, GB4S03, doi:10.1029/2006GB002726, 2006.

Beaufort, L., Probert, I., de Garidel-Thoron, T., Bendif, E. M., RuizPino, D., Metzl, N., Goyet, C., Buchet, N., Coupel, P., Grelaud, M., Rost, B., Rickaby, R. E. M., and de Vargas, C.: Sensitivity of coccolithophores to carbonate chemistry and ocean acidification, Nature, 476, 7358, doi:10.1038/nature10295, 2011.

Boeckel, B. and Baumann, K. H.: Distribution of coccoliths in the surface sediments of the south-eastern South Atlantic Ocean: ecology, preservation and carbonate distribution, Mar. Micropaleontol., 51, 301-320, 2004.

Bowen, G. J., Beerling, D. J., Koch, P. L., Zachos, J. C., and Quattlebaum, T.: A humid climate state during the Paleocene/ Eocene Thermal Maximum, Nature, 432, 495-499, 2004.

Bown, P. R. (Ed.): Calcareous nannofossil biostratigraphy, Chapman and Hall, Kluwer Academic Publishers, 315 pp., 1998.

Bown, P. R., Lees, J. A., and Young, J. R.: Calcareous nannoplankton evolution and biodiversity through time, in: Coccolithophores: from molecular processes to global impact, edited by: Thierstein, H. R. and Young, J. R., 481-508, Springer, New York, 2004.

Bralower, T. J., Premoli Silva, I., Malone, M., and the Scientific Participants of Leg 198: Proceedings of the Ocean Drilling Program, Initial Report, V. 198, available at: http://www-odp.tamu. edu/publications/198_IR/198ir.htm, 2002a.

Bralower, T. J.: Evidence for surface water oligotrophy during the Paleocene-Eocene Thermal Maximum: Nannofossil assemblage data from Ocean Drilling Program Site 690, Maud Rise, Weddell Sea, Paleoceanography, 17, 1023, doi:10.1029/2001PA000662, 2002b.

Broecker, W. S.: The oceanic $\mathrm{CaCO}_{3}$ cycle, in: Treatise on Geochemistry, vol. 6, The oceans and marine geochemistry, edited by: Henry Elderfield, 529-549, Pergamon, Oxford, UK, 2003.

Cramer, B. S., Wright, J. D., Kent, D. V., and Aubry, M.-P.: Orbital climate forcing of $\mathrm{d}^{13} \mathrm{C}$ excursions in the late Paleoceneearly Eocene (chrons C24n-C25n), Paleoceanography, 18, 1097, doi:10.1029/2003PA000909, 2003.

Chun, C. O. J., Delaney, M. L., and Zachos, J. C.: Paleoredox changes across the Paleocene-Eocene thermal maximum, Walvis Ridge (ODP Sites 1262, 1263, and 1266): Evidence from Mn and U enrichment factors, Paleoceanography, 25, PA4202, doi:10.1029/2009PA001861, 2010.

Dedert, M., Stoll, H. M., Kars, S., Young, J. R., Shimizu, N., Lourens, L., Kroon, D., and Ziveri, P.: Temporally variable diagenetic overgrowth on deep-sea nannofossil carbonates across Palaeogene hyperthermals and implications for isotopic analyses, Marine Micropaleontology, submitted, 2012a.
Dedert, M., Stoll, H. M., Young, J. R., Shimuzi, N., Kanamaru, K., Lourens, L., Ziveri, P., and Kroon, D.: Continued productivity and robust calcification of calcareous nannoplankton during the PETM, to be submitted to Palaeogeogr. Palaeocl., 2012b.

Delille, B., Harlay, J., Zondervan, I., Jacquet, S., Chou, L., Wollast, R., Bellerby, R. G. J., Frankignoulle, M., Borges, A. V., Riebesell, U., and Gattuso, J. P.: Response of primary production and calcification to changes of $p \mathrm{CO}(2)$ during experimental blooms of the coccolithophorid Emiliania huxleyi, Global Biogeochem. Cy., 19, Gb2023, doi:10.1029/2004gb002318, 2005.

De Villiers, S., Greaves, M., and Elderfield, H.: An intensity ratio calibration method for the accurate determination of $\mathrm{Mg} / \mathrm{Ca}$ and $\mathrm{Sr} / \mathrm{Ca}$ of marine carbonates by ICP-AES, Geochem. Geophys. Geosyst., 3, 1001, doi:10.1029/2001GC000169, 2002.

Falkowski, P. G., Katz, M. E., Knoll, A. H., Quigg, A., Raven, J. A.,Schofield, O., and Taylor, F. J. R.: The evolution of modern eukaryotic phytoplankton, Science, 305, 354-360, 2004.

Gibbs, S. J., Bown, P. R., Sessa, J. A., Bralower, T. J., and Wilson, P. A.:, Nannoplankton extinction and origin across the Paleocene-Eocene thermal maximum, Science, 314, 1770-1773, doi:10.1126/science.1133902, 2006a.

Gibbs, S. J., Bralower, T. J., Bown, P. R., Zachos, J. C., and Bybell, L. M.: Shelf and open-ocean calcareous phytoplankton assemblages across the Paleocene-Eocene Thermal Maximum: implications for global productivity gradients, Geology, 34, 233-236, 2006b.

Gibbs, S. J., Stoll, H. M., Bown, P. R., and Bralower, T. J.: Ocean acidification and surface water carbonate production across the Paleocene - Eocene Thermal Maximum, Earth Planet. Sci. Lett., 295, 583-592, doi:10.1016/j.eps1.2010.04.044, 2010.

Huber, M. and Sloan, L. C.: Warm climate transitions: a general circulation modeling study for the Late Paleocene Thermal Maximum ( 56 Ma), J. Geophys. Res., 104, 16633-16655, 1999.

Huber, M. and Sloan, L. C.: Climatic responses to tropical sea surface temperature changes on a "Greenhouse" Earth, Paleoceanography, 15, 443-450, 2000.

Huber, M. and Sloan, L.C.: Heat transport, deep waters, and thermal gradients: coupled simulation of an Eocene "greenhouse" climate, Geophys. Res. Let., 28, 3481-3484, 2001.

Jahn, B., Donner, B., Muller, P. J., Röhl, U., Schneider, R. R., and Wefer, G.: Pleistocene variations in dust input and marine productivity in the northern Benguela Current: evidence of evolution of global glacial-interglacial cycles, Palaeogeogr. Palaeocl., 193, 515-533, 2003.

Jiang, S. and Wise Jr., S. W.: Surface-water chemistry and fertility variations in the tropical Atlantic across the Paleocene-Eocene Thermal Maximum as evidenced by calcareous nannoplankton from ODP Leg 207, Hole 1259B, Revue de Micropaleontologie, 49, 227-244, 2006.

Jiang, S. and Wise Jr., S. W.: Distinguishing the influence of diagenesis on the paleoecological reconstruction of nannoplankton across the Paleocene-Eocene Thermal Maximum: an example from the Kerguelen Plateau, Southern Indian Ocean, Mar. Micropaleontol., 72, 49-59, 2009.

Klaas, C. and Archer, D.: Association of sinking organic matter with various types of mineral ballast in the deep sea: implications for the rain ratio, Global Biogeochem. Cy., 16, 1116, doi:10.1029/2001GB001765, 2002.

Krug, S. A., Schulz, K. G., and Riebesell, U.: Effects of changes 
in carbonate chemistry speciation on Coccolithus braarudii: a discussion of coccolithophorid sensitivities, Biogeosciences, 8, 771-777, doi:10.5194/bg-8-771-2011, 2011.

Langer, G., Geisen, M., Baumann, K. H., Klas, J., Riebesell, U., Thoms, S., and Young, J. R.: Species-specific responses of calcifying algae to changing seawater carbonate chemistry, Geochem. Geophys. Geosyst., 7, Q09006, doi:10.1029/2005GC001227, 2006.

Langer, G., Nehrke, G., Probert, I., Ly, J., and Ziveri, P.: Strain-specific responses of Emiliania huxleyi to changing seawater carbonate chemistry, Biogeosciences, 6, 2637-2646, doi:10.5194/bg-6-2637-2009, 2009.

Lourens, L. J., Sluijs, A., Kroon, D., Zachos, J. C., Thomas, E., Rohl, U., Bowles, J., and Raffi, I.: Astronomically pacing of late Palaeocene to early Eocene global warming events, Nature, 435, 1083-1087, 2005.

Minoletti F., Gardin, S., Nicot, E., Renard, M., and Spezzaferri, S.: A new experimental protocol for granulometric separation of calcareous nannofossil assemblages: palaeoecological and geochemical applications, B. Soc. Geol. Fr., 172, 437-446, 2001.

Murphy, B. H., Zachos, J. C., McCarren, H. K., Thomas, E., and Roehl, U.: High resolution records of the Elmo Event at Shatsky Rise, IODP Sites 1209 and 1211, available at: http: //adsabs.harvard.edu/abs/2006AGUFMPP23C1777M, 2005.

Mutterlose, J., Linnert, C., and Norris, D.: Calcareous nannofossils from the Paleocene-Eocene Thermal Maximum of the equatorial Atlantic (ODP Site 1260B): evidence for tropical warming, Mar. Micropaleontol., 65, 13-31, 2007.

Nicolo, M. J., Dickens, G. R., Hollis, C. J., and Zachos, J. C.: Multiple early Eocene hyperthermals; their sedimentary expression on the New Zealand continental margin and in the deep sea, Geology, 35, 699-702, 2007.

Perch-Nielsen, K.: Cenozoic calcareous nannofossils, in: Plankton Stratigraphy, edited by: Bolli, H. M., Saunders, J. B., and PerchNielsen, K., 427-554, Cambridge University Press, Cambridge, 1985.

Raffi, I. and de Bernardi, B.: Response of calcareous nannofossils to the Paleocene-Eocene Thermal Maximum: observations on composition, preservation and calcification in sediments from ODP Site 1263 (Walvis Ridge - SW Atlantic), Mar. Micropaleontol., 69, 119-138, 2008.

Ravizza, G., Norris, R. N., Blusztajn, J., and Aubry, M. P.: An Osmium isotope excursion associated with the late Paleocene Thermal Maximum: Evidence of intensified chemical weathering, Paleoceanography, 16, 155-163, 2001.

Rickaby, R. E. M., Schrag, D. P., Zondervan, I., and Riebesell, U.: Growth rate dependence of $\mathrm{Sr}$ incorporation during calcification of Emiliania huxleyi, Global Biogeochem. Cy., 16, 1006, doi:10.1029/2001GB001408, 2002.

Riebesell, U., Zondervan, I., Rost, B., Tortell, P. D., Zeebe, R. E., and Morel, F. M. M.: Reduced calcification of marine phytoplankton in response to increased atmospheric $\mathrm{CO}_{2}$, Nature, 407, 364-367, 2000.

Richter, F. M. and Liang, Y.: The rate and consequences of Sr diagenesis in deep-sea carbonates, Earth Plane. Sci. Lett., 117, 553$565,1993$.

Ridgwell, A. and Schmidt, D. N.: Past constraints on the vulnerability of marine calcifiers to massive carbon dioxide release, Nat. Geosci., 3, 196-200, doi:10.1038/ngeo755, 2010.
Ridgwell, A and Zeebe, R. E.: The role of the global carbonate cycle in the regulation and evolution of the earth system, Earth Planet. Sci. Lett., 234, 299-315, 2005.

Schneider, R. R., Muller, P. J., Ruhland, G., Meineke, G., Schmidt, H., and Wefer, G.: Late Quaternary surface temperature and productivity in the east-equatorial South Atlantic: response to changes in trade/ monsoon wind forcing and surface water advection, in: The South Atlantic: Present and Past circulation, edited by: Wefer, G., Berger, W. H., Siedler, G., and Webb, D. J., 527-551, Springer, Berlin, 1996.

Sexton, P. F., Norris, R. D., Wilson, P. A., Pälike, H., Westerhold, T., Röhl, U., Bolton, C. T., and Gibbs, S.: Eocene global warming events driven by ventilation of oceanic dissolved organic carbon, Nature, 471, 349-352, doi:10.1038/nature09826, 2011.

Sloan, L. C. and Huber, M.: Eocene oceanic responses to orbital forcing on precessional time scales, Paleoceanography, 16, 101$111,2001$.

Stap, L., Sluijs, A., Thomas, E., and Lourens, L.: Patterns and magnitude of deep sea carbonate dissolution during the Eocene Thermal Maximum 2 and H2, Walvis Ridge, Southeastern Atlantic Ocean, Paleoceanography, 24, PA1211, doi:10.1029/2008PA001655, 2009.

Stap, L., Lourens, L., van Dijk, A., Schouten, S., and Thomas, E.: Coherent pattern and timing of the carbon isotope excursion and warming during Eocene Thermal Maximum 2 as recorded in planktic and benthic foraminifera, Geochem. Geophys. Geosyst., 11, Q11011, doi:10.1029/2010GC003097, 2010a.

Stap, L., Lourens, L., Thomas, E., Sluijs, A., Bohaty, S., and Zachos, J.,C.: High-resolution deep-sea carbon and oxygen isotope records of Eocene Thermal Maximum 2 and H2, Geology, 38, 607-610, doi:10.1130/G30777.1, 2010b.

Stoll, H. M. and Bains, S.: Coccolith $\mathrm{Sr} / \mathrm{Ca}$ records of productivity during the Paleocene-Eocene Thermal Maximum from the Weddell Sea, Paleoceanography, 18, 1049, doi:10.1029/2002PA000875, 2003.

Stoll, H. M. and Schrag, D. P.: Effects of Quaternary sea level changes on strontium in seawater, Geochim. Cosmochim. Acta, 62, 1107-1118, 1998.

Stoll, H. M. and Schrag, D. P.: Sr/Ca variations in Cretaceous carbonates: relation to productivity and sea level changes, Palaeogeography, Palaeoclimatology, Palaeoecology, 168, 311-336, 2001.

Stoll, H. M. and Shimizu, N.: Micro-picking of nannofossils in preparation for analysis by secondary ion mass spectrometry, Nat. Protoc., 4, 1038-1043, 2009.

Stoll, H. M. and Ziveri, P.: Separation of monospecific and restricted coccolith assemblages from sediments using differential settling velocity, Mar. Micropaleontol., 46, 209-221, 2002.

Stoll, H. M., Klaas, C., Probert, I., Ruiz-Encinar, J., and GarciaAlonso, J. I.: Calcification rate and temperature effects on Sr partitioning in coccoliths of multiple species of coccolithophorids in culture, Global Planet. Change, 34, 153-171, 2002a.

Stoll, H. M., Rosenthal, Y., and Falkowski, P.: Climate proxies from the $\mathrm{Sr} / \mathrm{Ca}$ of coccolith calcite: calibrations from continuous culture of Emiliania huxleyi, Geochim. Cosmochim. Acta, 66, 927936, 2002b.

Stoll, H. M., Ziveri, P., Shimizu, N., Conte, M. H., and Theroux, S.: Relationship between coccolith $\mathrm{Sr} / \mathrm{Ca}$ ratios and coccolithophore production and export in the Arabian Sea and Sargasso Sea, 
Deep-sea Res. II, 54, 581-600, doi:10.1016/j.dsr2.2007.01.003, 2007a.

Stoll, H. M., Shimizu, N., Archer, D., and Ziveri, P.: Coccolithophore productivity response to greenhouse event of the Paleocene-Eocene Thermal Maximum, Earth Planet. Sci. Lett., 258, 192-206, 2007b.

Stoll, H. M., Shimizu, N., Arevalos, A., Matell, N., Banasiak, A., and Zeren, S.: Insights on coccolith chemistry from a new ion probe method for analysis of individually picked coccoliths, Geochem. Geophys. Geosyst., 8, Q06020, doi:10.1029/2006GC001546, 2007c.

Sweeney, E. N., McGillicuddy Jr., D. J., and Buesseler, K. O.: Biogeochemical impacts due to mesoscale eddy activity in the Sargasso Sea as measured at the Bermuda Atlantic time - series Study (BATS), Deep-sea Res. II, 50, 3017-3039, 2003.

Torfstein, A., Winckler, G., and Tripati, A.: Productivity feedback did not terminate the Paleocene-Eocene Thermal Maximum (PETM), Clim. Past, 6, 265-272, doi:10.5194/cp-6-265-2010, 2010.

Tremolada, F. and Bralower, T. J.: Nannofossil assemblage flucuations during the Paleocene- Eocene Thermal maximum at sites 213 (Indian Ocean) and 401 (North Atlantic Ocean): palaeoceanographical implications, Mar. Micropaleontol., 52, 107-116, 2004.

West, S., Jansen, J. H. F., and Stuut, J.-B.: Surface water conditions in the Northern Benguela Region (SE Atlantic) during the last $460 \mathrm{kyr}$ reconstructed from assemblages of planktonic forams, Mar. Micropaleontol., 51, 321-344, 2004.

Westerhold, T., Rohl, U., McCarren, H. K., and Zachos, J. C.: Latest on the absolute age of the Paleocene Eocene thermal maximum (PETM): new insights from exact stratigraphic position of key ash layers +19 and -17 , Earth Planet. Sci. Lett., 287, 412-419, 2009.
Young, J. R.: Functions of coccoliths, in: Coccolithophores, edited by: Winter, A. and Sissler, W., 63-82, Cambridge University Press, Cambridge, UK, 1994.

Young, J. R. and Ziveri, P.: Calculation of coccolith volume and its use in carbonate flux estimates, Deep-Sea Res. Part II, Topical Studies in Oceanography, 47, 1679-1700, 2000.

Zachos, J.C., Kroon, D., Blum, p., et al.: Proc. ODP Init. Rep., 208, available at: http://www-odp.tamu.edu/publications/ 208_IR/208ir.htm, 2004.

Zachos, J. C., Rohl, U., Schellenberg, S. A., Sluijs, A., Hodell, D. A., Kelly, D. C., Thomas, E., Nicolo, M., Raffi, I., Lourens, L., McCarren, H., and Kroon, D.: Rapid acidification of the ocean during the Paleocene- Eocene Thermal Maximum, Science, 308, 1611-1615, 2005

Zachos, J. C., McCarren, H., Murphy, B., Rohl, U., and Westerhold, T.: Tempo and scale of late Paleocene and early Eocene carbon isotope cycles: implications for the origin of hyperthermals, Earth Planet. Sci. Lett., 299, 242-249, 2010.

Ziveri, P. and Thunell, R.: Coccolithophore export production in Guaymas Basin, Gulf of California: Response to climate forcing, Deep-Sea Res., 47, 2073-2100, 2000.

Ziveri, P., Thunell, R., and Rio, D.: Export production of coccolithophores in an upwelling region: results from San Pedro Basin, Southern California Bight, Mar. Micropaleontol., 24, 335-358, 1995

Ziveri, P., De Bernardi, B., Baumann, K.-H., Stoll, H. M., and Mortyn, P. G.: Sinking of coccolith carbonate and potential contribution to organic carbon ballasting in the deep ocean, DeepSea Res. II, 54, 659-675, 2007. 